\title{
PCAT6 May Be a Whistler and Checkpoint Target for Precision Therapy in Human Cancers
}

\author{
Feng Jiang ${ }^{1,2}$, Qiaoyi $\mathrm{Lv}^{1,2}$, Cexun $\mathrm{Hu}^{1,2}$, Zhanghui $\mathrm{Li}^{1,2}$, Haojie Wu ${ }^{1,2}$, Shujun Gao ${ }^{1,2}$, Hui Wang ${ }^{1,2}$, \\ Yangjing Zhao ${ }^{1,2, *}$ and Qixiang Shao ${ }^{1,2,3, *(D)}$ \\ 1 Jiangsu Key Laboratory of Medical Science and Laboratory Medicine, Department of Immunology, \\ Reproductive Sciences Institute, School of Medicine, Jiangsu University, Zhenjiang 212013, China; \\ jiang_wax@163.com (F.J.); 2212113104@stmail.ujs.edu.cn (Q.L.); 2211913059@stmail.ujs.edu.cn (C.H.); \\ 2212013001@stmail.ujs.edu.cn (Z.L.); whjsnow1990@126.com (H.W.); gaoshujun95@163.com (S.G.); \\ 1000004613@ujs.edu.cn (H.W.) \\ 2 Jiangsu Key Laboratory of Medical Science and Laboratory Medicine, Department of Pathology, School of \\ Medicine, Jiangsu University, Zhenjiang 212013, China \\ 3 Institute of Medical Genetics and Reproductive Immunity, School of Medical Science and Laboratory \\ Medicine, Jiangsu College of Nursing, Huai'an 223002, China \\ * Correspondence: 1000005289@ujs.edu.cn (Y.Z.); shao_qx@ujs.edu.cn (Q.S.)
}

check for updates

Citation: Jiang, F.; Lv, Q.; Hu, C.; Li, Z.; Wu, H.; Gao, S.; Wang, H.; Zhao, Y.; Shao, Q. PCAT6 May Be a Whistler and Checkpoint Target for Precision Therapy in Human Cancers. Cancers 2021, 13, 6101. https:/ / doi.org/10.3390/cancers13236101

Academic Editor: Rory Johnson

Received: 19 October 2021

Accepted: 29 November 2021

Published: 3 December 2021

Publisher's Note: MDPI stays neutral with regard to jurisdictional claims in published maps and institutional affiliations.

Copyright: (c) 2021 by the authors. Licensee MDPI, Basel, Switzerland. This article is an open access article distributed under the terms and conditions of the Creative Commons Attribution (CC BY) license (https:/ / creativecommons.org/licenses/by/ $4.0 /)$.
Simple Summary: Prostate cancer-associated transcript 6 (PCAT6), as a newly discovered carcinogenic long non-coding RNA (lncRNA), is abnormally expressed in multiple diseases. With the accumulation of studies on PCAT6, we have a deeper understanding of its biological functions and mechanisms. Therefore, in this review, the various molecular mechanisms by which PCAT6 promotes multiple tumorigenesis and progression are summarized and discussed. Furthermore, its potential diagnostic, prognostic, and immunotherapeutic values are also clarified.

Abstract: LncRNAs are involved in the occurrence and progressions of multiple cancers. Emerging evidence has shown that PCAT6, a newly discovered carcinogenic lncRNA, is abnormally elevated in various human malignant tumors. Until now, PCAT6 has been found to sponge various miRNAs to activate the signaling pathways, which further affects tumor cell proliferation, migration, invasion, cycle, apoptosis, radioresistance, and chemoresistance. Moreover, PCAT6 has been shown to exert biological functions beyond ceRNAs. In this review, we summarize the biological characteristics of PCAT6 in a variety of human malignancies and describe the biological mechanisms by which PCAT6 can facilitate tumor progression. Finally, we discuss its diagnostic and prognostic values and clinical applications in various human malignancies.

Keywords: lncRNA; PCAT6; biological function; molecular mechanism; signaling pathway; oncogenic biomarker

\section{Introduction}

In recent years, with the development of RNA sequencing (RNAseq) technology, such as next-generation sequencing (NGS) and the third generation sequencing (TGS), more and more non-coding RNAs (ncRNAs) have been discovered, which occupy the majority of the transcriptome ( $90 \%)$ [1]. Unlike protein-coding genes, ncRNAs do not encode proteins or short peptides. According to whether they are more than 200 nucleotides in length, ncRNAs are divided into two categories: short ncRNAs and long ncRNAs (lncRNAs) [2,3]. LncRNAs participate in a variety of biological processes, such as individual ontogenetic development, cell or tissue development and differentiation, cell proliferation, cell death, cell cycle, migration, and invasion [4-6], and numerous pathological conditions, including cancer [7-9]. Moreover, lncRNAs play indispensable roles in regulating gene expression via epigenetic modification, transcriptional activation or interference, and post-transcriptional 
mechanism [10]. For example, lncRNAs can affect biological processes in various cancers by acting as competing endogenous RNAs (ceRNAs) or the sponge of microRNAs [11-13], or by directly regulating target proteins $[14,15]$. Recently, increasing evidence has revealed that lncRNAs are closely related to the clinicopathological features of various diseases, and have better diagnostic and prognostic value [16,17]. In short, lncRNAs are likely to serve as tumor biomarkers and therapeutic targets $[18,19]$.

Prostate cancer-associated transcript 6 (PCAT6) is a novel lncRNA that extensively promotes multiple cancer progression. Many investigations have demonstrated that the expression of PCAT6 is up-regulated in a variety of cancers and closely related to the occurrence and development of tumors [20,21]. Therefore, PCAT6 may be a potential target for cancer diagnosis and treatment. This review aims to summarize the abnormal expression and subcellular localization of PCAT6, and to further understand the underlying mechanisms, and its diagnostic or prognostic values in multiple human cancers.

\section{The Discovery of PCAT6}

PCAT6, a newly discovered lncRNA, is also named KDM5B-AS1, KDM5BAS1, PCAN$R 1, n c R N A-a 2$, or onco-lncRNA-96. It was first described as $n c R N A-a 2$ in 2010 [22]. The gene of PCAT6 is located on chromosome 1q32.1 and contains two exons. It consists of $968 \mathrm{bp}$ and has two transcript variants: transcript variant 1 (NR_046325.1) and transcript variant 2 (NR_046326.1). The transcription direction of PCAT6 is positive (Figure 1a), and some transcription factors that bind to the promoter region can be found near the upstream $2000 \mathrm{bp}$ (chr1:202808946) and downstream $100 \mathrm{bp}$ (chr1:202811046) of its transcription start sites (chr1:202810946). In addition, the histones H3K4Me3 and H3K27Ac that recognize the promoter sequences are also found in this region, which further proves the existence of an active promoter. Moreover, the transcription factors near these regions are more likely to become the upstream transcription factors of PCAT6 to regulate its transcription (e.g., nescient helix-loop-helix 2, NHLH2) (Figure 1b). By analyzing the RNAseq data of normal tissue from the Human Protein Atlas database, it was found that human testis tissues had the highest expression level of PCAT6 [23]. Subsequently, Wan et al. first found that knockdown of PCAT6 inhibited cell proliferation, invasion, and increased early apoptosis in lung cancer [20]. Increasing numbers of studies have illustrated that high expression levels of PCAT6 are associated with many human cancers.

\section{a}

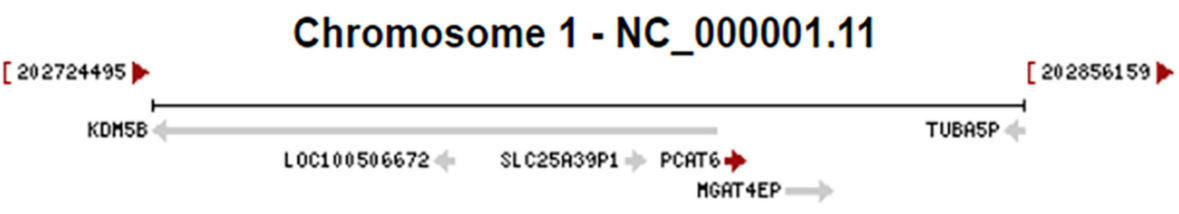

b

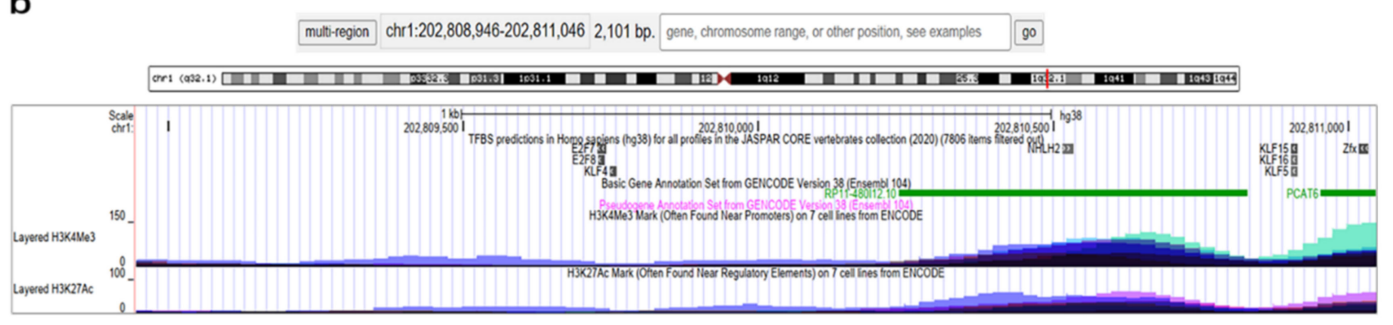

Figure 1. Transcription direction and upstream transcription factors of PCAT6. (a) The red arrow following PCAT6 points in the direction of transcription. Reference information comes from the National Center for Biotechnology Information (https: / /www.ncbi.nlm.nih.gov/gene/100506696 (accessed on 13 July 2021)). (b) Transcription factors that may regulate PCAT6, including NHLH2. Reference information comes from the University of California Santa Cruz (UCSC) Genome Browser (http:/ / genome.ucsc.edu/ (accessed on 13 July 2021)). 


\section{Expression and Subcellular Localization of PCAT6 \\ 3.1. The Abnormal Expression of PCAT6 in Cancers}

The expression of PCAT6 is found to be aberrantly elevated in various human tumor tissues and cell lines compared with matched normal ones, including bladder cancer (BC) $[21,24,25]$, breast cancer (BrCa) [26,27], cervical cancer (CC) [28,29], colorectal cancer (CRC) [30,31], gastrointestinal stromal tumor (GIST) [32], gastric cancer (GC) [33,34], glioblastoma (GBM) [35], hepatocellular carcinoma (HCC) [36-38], lung cancer (LC) [20,39-43], osteosarcoma (Osa) [44-46], ovarian cancer (OvCa) [47,48], cholangiocarcinoma (CCA) [49], pituitary adenoma (PA) [50], pancreatic ductal adenocarcinoma (PDAC) [51], and prostate cancer (PCa) $[52,53]$. In subsequent experiments on the biological functions of tumor cells, it has been revealed that a high level of PCAT6 has strong cancer-promoting effects, mainly including the promotion of cell proliferation, enhancement of migration, invasion and EMT process, as well as the inhibition of cell apoptosis. Meanwhile, PCAT6 has been shown to promote tumor growth and metastasis in xenograft mouse models (Table 1) $[26,29,30,38-40,43,44,46,50,52-54]$. However, Amelia et al. reported that the expression level of PCAT6 was opposite in lung tumor tissues and lung cancer cell lines compared with the normal control group [55]. Compared with paired normal tissue, PCAT6 expression level is higher in lung tumors, while its level is lower in non-small cell lung cancer (NSCLC) cell lines compared to the normal human fetal lung fibroblast cell line (IMR-90) [55]. Interestingly, Tu et al. found that, compared to T cells, B cells, dendritics, and neutrophils, PCAT6 expression was the highest in macrophages which derived from patients of CCA, especially M2 macrophages [54]. Furthermoer, PCAT6 expression level is also significantly higher in the blood samples of some cancer patients, including BC [24] and LC [41,56]. Contradictorily, Siddique et al., testified that PCAT6 level had no significant difference in the blood between Saudi CRC patients and healthy donors [57]. It is speculated that the cause of this result may be ethnically related, and the expression level of PCAT6 in CRC patients of different races might be different.

Table 1. Functional characterization of PCAT6 in multiple human cancers.

\begin{tabular}{|c|c|c|c|c|c|c|c|}
\hline $\begin{array}{l}\text { Tumor } \\
\text { Types }\end{array}$ & Expression & Sample Type & Role & Functional Role in Vitro & $\begin{array}{c}\text { Functional } \\
\text { Role in Vivo }\end{array}$ & $\begin{array}{c}\text { Related } \\
\text { Genes/Protein/Pathways }\end{array}$ & Ref. \\
\hline \multirow[t]{3}{*}{$\begin{array}{l}\text { Bladder } \\
\text { cancer }\end{array}$} & $\mathrm{Up}$ & $\begin{array}{l}\text { cells (RT4, T24, J82, } \\
\text { UMUC3, 5637), } \\
\text { patient tissue and } \\
\text { serum }\end{array}$ & $\begin{array}{l}\text { Tumor } \\
\text { promoter }\end{array}$ & $\begin{array}{l}\text { Cell proliferation and } \\
\text { apoptosis }\end{array}$ & & NA & [24] \\
\hline & $\mathrm{Up}$ & $\begin{array}{l}\text { Cells (T24, EJ, 253j, } \\
\text { 5637), patient tissue }\end{array}$ & $\begin{array}{l}\text { Tumor } \\
\text { promoter }\end{array}$ & $\begin{array}{l}\text { Cell proliferation, } \\
\text { migration, and invasion }\end{array}$ & & $\operatorname{miR}-513 a-5 p$ & [21] \\
\hline & Up & $\begin{array}{l}\text { Cells (T24T, EJ, } \\
\text { UMUC3, 5637), } \\
\text { patient tissue }\end{array}$ & $\begin{array}{l}\text { Tumor } \\
\text { promoter }\end{array}$ & $\begin{array}{l}\text { Cell proliferation, } \\
\text { migration, and invasion }\end{array}$ & & miR-143-3p, PDIA6 & [25] \\
\hline \multirow[t]{2}{*}{$\begin{array}{l}\text { Breast } \\
\text { cancer }\end{array}$} & $\mathrm{Up}$ & $\begin{array}{l}\text { Cells (MDA-MB-231, } \\
\text { MDA-MB-468, } \\
\text { MDA-MB-436, } \\
\text { HCC-1937), patient } \\
\text { tissue }\end{array}$ & $\begin{array}{l}\text { Tumor } \\
\text { promoter }\end{array}$ & $\begin{array}{l}\text { Cell proliferation, } \\
\text { migration, invasion, EMT } \\
\text { process, and angiogenesis }\end{array}$ & $\begin{array}{l}\text { Tumor } \\
\text { growth, } \\
\text { metastasis, } \\
\text { and } \\
\text { angiogenesis }\end{array}$ & $\begin{array}{c}\text { VEGF, } \\
\text { VEGFR2/Akt/mTOR, } \\
\text { miR-4723-5p, USP14, } \\
\text { E-cadherin, N-cadherin, } \\
\text { Slug, Twist, }\end{array}$ & [26] \\
\hline & Up & $\begin{array}{l}\text { Cells (MDA-MB-468, } \\
\text { MDA-MB-231), } \\
\text { patient tissue }\end{array}$ & $\begin{array}{l}\text { Tumor } \\
\text { promoter }\end{array}$ & $\begin{array}{l}\text { Cell proliferation, } \\
\text { apoptosis, cell cycle, and } \\
\text { radiosensitivity }\end{array}$ & & miR-185-5p, TPD52 & [27] \\
\hline \multirow[t]{2}{*}{$\begin{array}{l}\text { Cervical } \\
\text { cancer }\end{array}$} & Up & $\begin{array}{l}\text { Cells (Caski, SW756, } \\
\text { HeLa, ME-180, SiHa, } \\
\text { C33A), patient tissue }\end{array}$ & $\begin{array}{l}\text { Tumor } \\
\text { promoter }\end{array}$ & $\begin{array}{c}\text { Cell proliferation, } \\
\text { apoptosis, migration, and } \\
\text { invasion }\end{array}$ & & $\begin{array}{c}\text { Wnt } / \beta \text {-catenin, } \\
\beta \text {-catenin, cyclin D1, } \\
\text { c-myc }\end{array}$ & [28] \\
\hline & Up & $\begin{array}{c}\text { Cells (SiHa, HeLa, } \\
\text { ME180, C-33A), } \\
\text { patient tissue }\end{array}$ & $\begin{array}{l}\text { Tumor } \\
\text { promoter }\end{array}$ & $\begin{array}{l}\text { Cell proliferation, } \\
\text { apoptosis, migration, } \\
\text { invasion, and } \\
\text { chemoresistance }\end{array}$ & $\begin{array}{l}\text { Tumor } \\
\text { growth }\end{array}$ & $\begin{array}{c}\text { miR-543, Bcl-2, } \\
\text { cleaved-caspase 3, ZEB1 }\end{array}$ & [29] \\
\hline
\end{tabular}


Table 1. Cont.

\begin{tabular}{|c|c|c|c|c|c|c|c|}
\hline $\begin{array}{l}\text { Tumor } \\
\text { Types }\end{array}$ & Expression & Sample Type & Role & Functional Role in Vitro & $\begin{array}{l}\text { Functional } \\
\text { Role in Vivo }\end{array}$ & $\begin{array}{c}\text { Related } \\
\text { Genes/Protein/Pathways }\end{array}$ & Ref. \\
\hline \multirow[t]{2}{*}{$\begin{array}{l}\text { Colorectal } \\
\text { cancer }\end{array}$} & $\mathrm{Up}$ & $\begin{array}{c}\text { Cells (SW628, SW480, } \\
\text { RKO, COLO320HSR, } \\
\text { HCT116), patient } \\
\text { tissue }\end{array}$ & $\begin{array}{l}\text { Tumor } \\
\text { promoter }\end{array}$ & $\begin{array}{l}\text { Cell proliferation and } \\
\text { apoptosis }\end{array}$ & $\begin{array}{l}\text { Tumor } \\
\text { growth }\end{array}$ & $\begin{array}{c}\text { Cleaved-caspase 3, ARC, } \\
\text { EZH2 }\end{array}$ & [30] \\
\hline & $\mathrm{Up}$ & $\begin{array}{c}\text { Cells (HCT116, } \\
\text { HT-29, SW620, } \\
\text { SW480, DLD-1, RKO, } \\
\text { LoVo), patient tissue }\end{array}$ & $\begin{array}{l}\text { Tumor } \\
\text { promoter }\end{array}$ & $\begin{array}{l}\text { Cell proliferation and } \\
\text { chemoresistance }\end{array}$ & & $\begin{array}{c}\text { miR-204, HMGA2, PI3K, } \\
\text { Akt }\end{array}$ & [31] \\
\hline $\begin{array}{l}\text { Gastro } \\
\text { intestinal } \\
\text { stromal } \\
\text { tumor }\end{array}$ & $\mathrm{Up}$ & $\begin{array}{c}\text { Cells (GIST-H1, } \\
\text { GIST-882, GIST-T1, } \\
\text { GIST-48), patient } \\
\text { tissue }\end{array}$ & $\begin{array}{l}\text { Tumor } \\
\text { promoter }\end{array}$ & $\begin{array}{c}\text { Cell proliferation, } \\
\text { stemness, and apoptosis }\end{array}$ & & $\begin{array}{c}\text { Wnt/ } \beta \text {-catenin, } \\
\text { miR-143-3p, PRDX5 }\end{array}$ & {$[32]$} \\
\hline \multirow[t]{2}{*}{$\begin{array}{l}\text { Gastric } \\
\text { cancer }\end{array}$} & $\mathrm{Up}$ & $\begin{array}{l}\text { Cells (BGC-823, } \\
\text { SGC-7901, HGC-27, } \\
\text { MKN45), patient } \\
\text { tissue }\end{array}$ & $\begin{array}{l}\text { Tumor } \\
\text { promoter }\end{array}$ & $\begin{array}{l}\text { Cell proliferation, } \\
\text { migration, EMT, and } \\
\text { apoptosis }\end{array}$ & & $\begin{array}{l}\text { miR-30, MKRN3, caspase } \\
\text { 3, caspase 9, Bax, Bcl-2, } \\
\text { E-cadherin, N-cadherin, } \\
\text { Vimentin, ZEB1, Snail }\end{array}$ & [34] \\
\hline & $\mathrm{Up}$ & $\begin{array}{l}\text { Cells (MKN45, } \\
\text { SGC-7901, AGS, } \\
\text { MKN28), patient } \\
\text { tissue }\end{array}$ & $\begin{array}{l}\text { Tumor } \\
\text { promoter }\end{array}$ & $\begin{array}{l}\text { Cell proliferation, EMT, } \\
\text { and apoptosis }\end{array}$ & & $\begin{array}{l}\text { Cyclin D1, p53, Bax, } \\
\text { cleaved caspase 3, } \\
\text { E-cadherin, N-cadherin, } \\
\text { Vimentin, Snail, ZEB1, } \\
\text { miR-15a, RB/E2F, } \\
\text { Wnt/ } \beta \text {-catenin }\end{array}$ & [33] \\
\hline Glioblastoma & $\mathrm{Up}$ & $\begin{array}{l}\text { Cells (A172, U251, } \\
\text { U87, LN229), patient } \\
\text { tissue }\end{array}$ & $\begin{array}{l}\text { Tumor } \\
\text { promoter }\end{array}$ & $\begin{array}{l}\text { Cell proliferation and } \\
\text { apoptosis }\end{array}$ & & $\begin{array}{c}\text { YY1, miR-513, IGF2BP1, } \\
\text { Akt }\end{array}$ & [35] \\
\hline \multirow{3}{*}{$\begin{array}{l}\text { Hepato } \\
\text { cellular } \\
\text { carci- } \\
\text { noma }\end{array}$} & Up & Patient tissue & $\begin{array}{l}\text { Tumor } \\
\text { promoter }\end{array}$ & $\begin{array}{l}\text { Cell proliferation and } \\
\text { migration }\end{array}$ & & NA & [36] \\
\hline & Up & $\begin{array}{c}\text { Cells (HuH7, } \\
\text { SMMC-7721, Hep3B, } \\
\text { HepG2, PLC/PRF/5), } \\
\text { patient tissue }\end{array}$ & $\begin{array}{l}\text { Tumor } \\
\text { promoter }\end{array}$ & $\begin{array}{l}\text { Cell proliferation, cycle, } \\
\text { apoptosis, and migration }\end{array}$ & & PCNA, CCND1, Bcl-2 & [37] \\
\hline & $\mathrm{Up}$ & $\begin{array}{l}\text { Cells (MHCC97H, } \\
\text { HepG2, Huh7), } \\
\text { patient tissue }\end{array}$ & $\begin{array}{l}\text { Tumor } \\
\text { promoter }\end{array}$ & $\begin{array}{l}\text { Cell proliferation and } \\
\text { invasion }\end{array}$ & $\begin{array}{l}\text { Tumor } \\
\text { growth }\end{array}$ & miR-326, hnRNPA2B1 & [38] \\
\hline \multirow{5}{*}{$\begin{array}{l}\text { Lung } \\
\text { cancer }\end{array}$} & $\mathrm{Up}$ & $\begin{array}{c}\text { Cells (H1650, } \\
\text { HCC827, H1975, } \\
\text { A549), patient tissue }\end{array}$ & $\begin{array}{l}\text { Tumor } \\
\text { promoter }\end{array}$ & $\begin{array}{l}\text { Cell proliferation, } \\
\text { migration, and invasion, }\end{array}$ & $\begin{array}{l}\text { Tumor } \\
\text { growth }\end{array}$ & $\operatorname{miR}-330-5 p$ & [39] \\
\hline & $\mathrm{Up}$ & $\begin{array}{c}\text { Cells (SK-MES-1, } \\
\text { H1703, H520, H1299, } \\
\text { H1975, SPCA1, } \\
\text { A549), patient tissue }\end{array}$ & $\begin{array}{l}\text { Tumor } \\
\text { promoter }\end{array}$ & $\begin{array}{l}\text { Cell proliferation, cycle, } \\
\text { apoptosis, migration, and } \\
\text { invasion }\end{array}$ & $\begin{array}{l}\text { Tumor } \\
\text { growth }\end{array}$ & EZH2, LATS2 & [40] \\
\hline & $\mathrm{Up}$ & $\begin{array}{l}\text { Cells (H292, PC-9, } \\
\text { CL1-5, H460, H1650, } \\
\text { A549, H446, H1975) }\end{array}$ & $\begin{array}{l}\text { Tumor } \\
\text { promoter }\end{array}$ & $\begin{array}{l}\text { Cell proliferation, } \\
\text { apoptosis, and invasion }\end{array}$ & & Bcl-2, Bax, c-myc, p53 & [20] \\
\hline & $\mathrm{Up}$ & $\begin{array}{l}\text { Cells (H446, H1975), } \\
\text { patient tissue }\end{array}$ & $\begin{array}{l}\text { Tumor } \\
\text { promoter }\end{array}$ & $\begin{array}{l}\text { Cell proliferation, } \\
\text { migration, invasion, and } \\
\text { apoptosis }\end{array}$ & & $\begin{array}{c}\text { c-myc, MMP9, } \\
\text { cleaved-caspase-3, Wnt5a, } \\
\beta \text {-catenin. miR-326. }\end{array}$ & {$[42]$} \\
\hline & $\mathrm{Up}$ & $\begin{array}{l}\text { Cells (H1838, H522, } \\
\text { H2228, H358, H1299, } \\
\text { A549), }\end{array}$ & $\begin{array}{l}\text { Tumor } \\
\text { promoter }\end{array}$ & $\begin{array}{l}\text { Cell proliferation, } \\
\text { migration, invasion, } \\
\text { cycle, apoptosis }\end{array}$ & $\begin{array}{l}\text { Tumor } \\
\text { growth }\end{array}$ & Caspase-3, Ki-67 & [43] \\
\hline \multirow{3}{*}{$\begin{array}{c}\text { Osteo } \\
\text { sarcoma }\end{array}$} & $\mathrm{Up}$ & $\begin{array}{l}\text { Cells (MG-63, Saos-2, } \\
\text { 143B, U2OS), patient } \\
\text { tissue }\end{array}$ & $\begin{array}{l}\text { Tumor } \\
\text { promoter }\end{array}$ & $\begin{array}{l}\text { Cell proliferation, } \\
\text { migration, invasion, and } \\
\text { cell cycle }\end{array}$ & $\begin{array}{l}\text { Tumor } \\
\text { growth }\end{array}$ & ZEB1, miR-143-3p & [44] \\
\hline & $\mathrm{Up}$ & $\begin{array}{l}\text { Cells (Saos2, MG63, } \\
\text { U2OS, HOS) }\end{array}$ & $\begin{array}{l}\text { Tumor } \\
\text { promoter }\end{array}$ & $\begin{array}{l}\text { Cell proliferation, } \\
\text { migration, and invasion }\end{array}$ & $\begin{array}{l}\text { Tumor } \\
\text { growth }\end{array}$ & $\begin{array}{l}\text { MMP2, MMP9, p53, p21, } \\
\text { MDM2 }\end{array}$ & {$[46]$} \\
\hline & $\mathrm{Up}$ & $\begin{array}{c}\text { Cells (Saos2, HOS, } \\
\text { U2OS, 143B, } \\
\text { KHOS/240S, MG63, } \\
\text { SK-ES-1), patient } \\
\text { tissue }\end{array}$ & $\begin{array}{l}\text { Tumor } \\
\text { promoter }\end{array}$ & $\begin{array}{l}\text { Cell proliferation, } \\
\text { migration, and invasion }\end{array}$ & & $\begin{array}{l}\text { miR-185-5p, TGF- } \beta \text {, } \\
\text { p-SMAD, TGFBR1/2 }\end{array}$ & [45] \\
\hline
\end{tabular}


Table 1. Cont.

\begin{tabular}{|c|c|c|c|c|c|c|c|}
\hline $\begin{array}{l}\text { Tumor } \\
\text { Types }\end{array}$ & Expression & Sample Type & Role & Functional Role in Vitro & $\begin{array}{l}\text { Functional } \\
\text { Role in Vivo }\end{array}$ & $\begin{array}{c}\text { Related } \\
\text { Genes/Protein/Pathways }\end{array}$ & Ref. \\
\hline \multirow[t]{2}{*}{$\begin{array}{l}\text { Ovarian } \\
\text { cancer }\end{array}$} & Up & $\begin{array}{l}\text { Cells (OVCAR3, } \\
\text { PEO1, A2780, 3AO, } \\
\text { CAOV3, SKOV3), } \\
\text { patient tissue }\end{array}$ & $\begin{array}{l}\text { Tumor } \\
\text { promoter }\end{array}$ & $\begin{array}{l}\text { Cell proliferation, } \\
\text { migration, and invasion }\end{array}$ & & PTEN & {$[47]$} \\
\hline & $\mathrm{Up}$ & Patient tissue & $\begin{array}{l}\text { Tumor } \\
\text { promoter }\end{array}$ & $\begin{array}{l}\text { Cell proliferation, } \\
\text { migration, and invasion }\end{array}$ & & miR-143-3p, TAK1 & {$[48]$} \\
\hline \multirow[t]{2}{*}{$\begin{array}{l}\text { Cholangio } \\
\text { carcinoma }\end{array}$} & $\mathrm{Up}$ & $\begin{array}{c}\text { Patient-derived } \\
\text { macrophages, patient } \\
\text { tissue }\end{array}$ & $\begin{array}{l}\text { Tumor } \\
\text { promoter }\end{array}$ & $\begin{array}{l}\text { M2 polarization of } \\
\text { macrophages, cellular } \\
\text { reactive oxygen species } \\
\text { production, } \\
\text { mitochondrial and } \\
\text { metabolic dysfunction }\end{array}$ & $\begin{array}{l}\text { Tumor } \\
\text { growth }\end{array}$ & $\begin{array}{c}\text { miR-326, RhoA, ROCK1, } \\
\text { ROCK2 }\end{array}$ & {$[54]$} \\
\hline & $\mathrm{Up}$ & $\begin{array}{l}\text { Cell (ICC-9810, } \\
\text { CCLP1, HuCC-T1, } \\
\text { QBC939), patient } \\
\text { tissue }\end{array}$ & $\begin{array}{l}\text { Tumor } \\
\text { promoter }\end{array}$ & $\begin{array}{l}\text { Cell proliferation and } \\
\text { invasion }\end{array}$ & & miR-330-5p & [49] \\
\hline $\begin{array}{l}\text { Pituitary } \\
\text { adeno- } \\
\text { mas }\end{array}$ & Up & Patient tissue & $\begin{array}{l}\text { Tumor } \\
\text { promoter }\end{array}$ & $\begin{array}{l}\text { Cell proliferation, } \\
\text { migration, invasion, } \\
\text { viability, apoptosis, cell } \\
\text { cycle, and EMT }\end{array}$ & $\begin{array}{l}\text { Tumor } \\
\text { growth, } \\
\text { apoptosis, } \\
\text { EMT }\end{array}$ & $\begin{array}{c}\text { miR-139-3p, BRD4, } \\
\text { E-cadherin, N-cadherin, } \\
\text { Bcl-2, Bax, } \\
\text { cleaved-caspase } 3\end{array}$ & {$[50]$} \\
\hline $\begin{array}{l}\text { Pancreatic } \\
\text { ductal } \\
\text { adeno- } \\
\text { carci- } \\
\text { noma }\end{array}$ & Up & $\begin{array}{l}\text { Cell (Capan-2, } \\
\text { AsPC-1, PANC1, } \\
\text { BxPC-3), Patient } \\
\text { tissue }\end{array}$ & $\begin{array}{l}\text { Tumor } \\
\text { promoter }\end{array}$ & $\begin{array}{l}\text { Cell proliferation, } \\
\text { migration, and invasion }\end{array}$ & & miR-185-5p, CBX2 & {$[51]$} \\
\hline \multirow[t]{2}{*}{$\begin{array}{l}\text { Prostate } \\
\text { cancer }\end{array}$} & Up & $\begin{array}{l}\text { Cell (NCI-H660), } \\
\text { patient tissue }\end{array}$ & $\begin{array}{l}\text { Tumor } \\
\text { promoter }\end{array}$ & $\begin{array}{l}\text { Cell NED, proliferation, } \\
\text { and invasion }\end{array}$ & $\begin{array}{l}\text { Tumor } \\
\text { growth and } \\
\text { metastasis }\end{array}$ & $\begin{array}{c}\text { NSE, SYP, ChgA, } \\
\text { miR-326, hnRNPA2B1 }\end{array}$ & {$[52]$} \\
\hline & $\mathrm{Up}$ & Patient tissue & $\begin{array}{l}\text { Tumor } \\
\text { promoter }\end{array}$ & $\begin{array}{l}\text { Cell proliferation, cycle, } \\
\text { migration, and invasion }\end{array}$ & $\begin{array}{l}\text { Tumor } \\
\text { growth and } \\
\text { BM }\end{array}$ & $\begin{array}{l}\text { IGF2BP2, IGF1R, } \\
\text { PI3K/Akt, NF-kB, } \\
\text { METTL3, ALKBH5 }\end{array}$ & {$[53]$} \\
\hline
\end{tabular}

PDIA6, protein disulfide isomerase family A number 6; EMT, epithelial-mesenchymal transition; VEGF, vascular endothelial growth factor; VEFGR2, vascular endothelial growth factor receptor 2; Akt, serine/threonine kinase; mTOR, mammalian target of rapamycin; USP14, ubiquitin-specific protease-14; TPD52, tumor protein D52; Bcl-2, B-cell lymphoma-2; ZEB1, zinc finger E-box binding homeobox 1; ARC, activity regulated cytoskeleton associated protein; EZH2, enhancer of zeste homolog 2; HMGA2, high mobility group AT-hook 2; PRDX5, peroxiredoxin 5; MKRN3, makorin ring finger protein 3; YY1, Yin Yang 1; IGF2BP1, insulin like growth factor 2 mRNA binding protein 1; IGF2BP2, insulin like growth factor 2 mRNA binding protein 2; PCNA, proliferating cell nuclear antigen; CCND1, cyclin D1; hnRNPA2B1, heterogeneous nuclear ribonucleoprotein A2/B1, LATS2, large tumor suppressor kinase 2; Bax, BCL2 associated X; MMP2, matrix metallopeptidase 2; MMP9, matrix metallopeptidase 9; MDM2, mouse double minute 2 homolog; TGF- $\beta$, transforming growth factor $\beta$; TGFBR1/2, transforming growth factor $\beta$ receptor $1 / 2$; PTEN, phosphatase and tensin homolog; TAK1, TGF- $\beta$ activated kinase 1; RhoA, ras homolog family member A; ROCK1/2, Rho associated coiled-coil containing protein kinase 1/2; BRD4, bromodomain containing 4; CBX2, chromobox 2; NED, neuroendocrine differentiation; SYP, synaptophysin; ChgA, chromogranin A; BM, bone metastasis; IGF1R, insulin like growth factor 1 receptor; METTL3, methyltransferase 3, N6-adenosine-methyltransferase complex catalytic subunit; ALKBH5, alkB homolog 5.

\subsection{The Subcellular Localization of PCAT6 in Cancer Cell Lines}

LncRNAs play diverse functions depending on different subcellular or extracellular compartmental localizations. Most studies indicate that PCAT6 is primarily located in the cytoplasm of BC [25], GIST [32], GBM [35], Osa [44,45], PA [50], and Pca [52] cells. Cytoplasmic lncRNAs regulate genes at the translational and post-transcriptional levels, such as interaction with cytoplasmic proteins [58], and interaction with microRNAs to regulate downstream mRNA levels [59-63]. Shi et al. determined that PCAT6 was principally distributed in the nucleus of NSCLC cells [40]. Nucleic lncRNAs regulate genes at the epigenetic and transcriptional levels, including histone modifications [64,65], DNA methylation [66], and chromatin remodeling [67]. Furthermore, Dong and Lang et al. demonstrated that PCAT6 was located in both the cytoplasm and nucleus of $\mathrm{BrCa}$ and $\mathrm{PCa}$ cells by fluorescence in situ hybridization (FISH) and subcellular fraction assays, which was different from most studies $[26,53]$. This is similar to the lncRNA HOTAIR, which regulates 
genes at both the epigenetic and transcriptional levels, as well as at the post-transcriptional level [68].

As shown in Figure 1a, PCAT6 is an antisense RNA of $K D M 5 B$, so it is also known as KDM5B-AS1. The RNAs PCAT6 and KDM5B are adjacent in chromosome position. Several antisense lncRNAs have been found to form RNA-RNA dimers with adjacent mRNA, thus improving the stability of mRNA and upregulating mRNA expression levels. For instance, lncRNA BACE1-AS1 can reduce the degradation of BACE1 by forming a dimer with BACE1 [69]; lncRNA FGFR3-AS1 promotes Osa through increasing FGFR3 stability [70]. Hence, we speculate that PCAT6 may also maintain the stability of KDM5B mRNA and upregulate the expression of the KDM5B protein, thus promoting disease progression, but this hypothesis needs to be further confirmed. Furthermore, PCAT6 is also regulated by different transcription factors. In addition to NHLH2 near H3K4Me3 and H3K27Ac (Figure 1b), transcription factors that have been confirmed to regulate PCAT6 include the Sp1 transcription factor (SP1) [71] and the enhancer of zeste homolog 2 (EZH2) [30,40].

\section{PCAT6 Promotes Cancer Progression by ceRNA Mechanisms}

LncRNAs can participate in the process of tumor progression via various molecular mechanisms, including by interacting with DNA, RNA, and protein. They play different regulatory roles by serving as different functional molecules, such as signals, decoys, guides, and scaffolds in multiple tumor cellular processes [22,72]. In recent studies, mounting evidence indicates that the lncRNA-miRNA-mRNA axis is present in cancers [73-77]. LncRNAs can mediate competitive mRNAs crosstalk by sharing microRNA response elements (MREs), which are also known as competing endogenous RNA (ceRNA) regulatory network mechanisms. Wang et al. first confirmed the existence of the lncRNA-related ceRNA mechanism in liver cancer. They determined that lncRNA HULC promoted liver cancer progression by regulating the miR-372/PRKACB axis [78]. Later on, Selmena et al. proposed the ceRNA hypothesis based on previous investigations [79]. Subsequently, more and more cancer-associated lncRNAs mediated ceRNA networks have been revealed. So far, more than 11,700,000 pairs of ceRNA have been included in the starBase database (http:/ / starbase.sysu.edu.cn/index.php (accessed on 28 July 2021)). The ceRNA regulatory networks have been proven to be the indispensable regulators of multiple tumors growth [80], and the PCAT6-centric ceRNA networks have attracted wide attention. PCAT6 promotes tumorigenesis through the PCAT6/miRNA/mRNA axis, which in turn affects different biological behaviors of tumor cells $[27,44]$. As shown in Figures $2-4,11$ miRNAs have been verified to interact with PCAT6, thus participating in the ceRNA networks of PCAT6. Meanwhile, as members of ceRNA, the miRNAs downatream of lncRNAs can directly or indirectly regulate mRNAs and thus affect the biological behaviors of tumor cells, such as proliferation, migration, invasion, apoptosis, cell cycles [27,37,40,43,44,50,53], epithelial-mesenchymal transitions (EMT) [26,33,34,50], radiosensitivity [27], and chemoresistance $[29,31]$.

\subsection{PCAT6 Boosts the PI3K/Akt/mTOR Signaling Pathway}

Phosphatidylinositol 3-kinase (PI3K), protein kinase B (PKB, also known as Akt), the mammalian target of the rapamycin (mTOR) signaling pathway, is vital for the regulation of cell biological functions in cancers, including cell proliferation, metastasis, cell apoptosis, autophagy, and glucose and lipid metabolism [81-83]. They are considered potential therapeutic targets and are involved in various biological processes in neoplasms. As shown in Figure 2, Dong et al. revealed that M2 macrophages secreted the vascular endothelial growth factor (VEGF) and upregulated the PCAT6 expression level in BrCa. PCAT6 overexpression further induced the Akt/mTOR pathway by absorbing miR-4723$5 p$ to elevate vascular endothelial growth factor receptor 2 (VEGFR2) levels, which in turn promoted triple-negative breast cancer (TNBC) cell proliferation, migration, invasion, and angiogenesis in vitro, as well as tumor growth, metastasis, and angiogenesis in vivo [26].Shi et al., also proved that PCAT6 increased the expression of tumor protein 
D52 (TPD52) by interacting with miR-185-5p in TNBC [27]. Another study suggested that TPD52 may exert a biological function via the PI3K/Akt signaling pathway [84]. In CRC, PCAT6 can increase the expression level of HMGA2 via absorbing miR-204, while depletion of PCAT6 can dramatically reduce the protein levels of HMGA2, p-PI3K, and p-Akt. Inhibition of miR-204 partially abolishes the suppressive effects of PCAT6 knockdown on these proteins. This evidence indicates that PCAT6 activates PI3K/Akt signaling by regulating the miR-204/HMGA2 axis and further promotes proliferation of CRC cells [31]. In addition, Liu et al. confirmed that PCAT6 was transcriptionally upregulated by the Yin Yang 1 (YY1) protein in GBM, which further activated Akt signaling by increasing insulin like growth factor 2 mRNA binding protein 1 (IGF2BP1) expression via inhibition of miR-513. Simultaneously, the stability of PCAT6 is enhanced by interacting with IGF2BP1. Furthermore, PCAT6, transcriptionally activated by YY1, promoted the proliferation and prevented the apoptosis of GBM cells through the PCAT6/miR-513/IGF2BP1 positive loop [35]. PCAT6 promotes HCC cell proliferation and invasion in vitro, and tumor growth in vivo by attenuating miR-326 and upregulating heterogeneous nuclear ribonucleoprotein A2/B1 (HNRNPA2B1) [38]. Moreover, enzalutamide induced PCAT6 also promotes PCa cell proliferation, metastasis, and neuroendocrine differentiation (NED) via the miR-326/HNRNPA2B1 axis in vitro or in vivo [52]. Several studies have clarified that HNRNPA2B1 can activate the PI3K/Akt/mTOR pathway [85-88], which further indicates that PCAT6 may induce this pathway through the ceRNA mechanism. In Osa, PCAT6 upregulates the transforming growth factor $\beta$ receptor $1 / 2$ (TGFBR1/2) expression by attenuating miR-185-5p, which further activates transforming growth factor $\beta$ (TGF- $\beta$ ) pathway-related proteins such as $\mathrm{p}-\mathrm{SMAD}$, thereby promoting the proliferation, migration, and invasion of Osa cells [45]. TGF- $\beta$ is verified to be associated with the PI3K/Akt signaling pathway [89-91]. Zhao et al., validated that PCAT6 promoted the progression of PA through miR-139-3p/bromodomain-containing protein 4 (BRD4) axis. Interference of PCAT6 or the accumulation of miR-139-3p impedes tumor growth, induces apoptosis and promotes the EMT process in vivo. The MiR-139-3p inhibitor significantly attenuates the regulatory effects of PCAT6 knockdown on cell viability, proliferation, apoptosis, and cell cycle arrest. The depletion of BRD4 reverses the promoting effects of the miR-139-3p inhibitor on PA cell viability, proliferation, migration, and invasion [50]. BRD4 has been experimentally confirmed to be associated with PI3K/Akt signaling [92-94]. Additionally, a study has elucidated that PI3K/Akt pathway can be activated by circ_0007841/miR-3383p/BRD4 axis [95], which indicates PCAT6 may activate the PI3K/Akt pathway through the BRD4 ceRNA mechanism. Wang et al. clarified that PCAT6 acted as a sponge for miR185-5p to increase chromobox 2 (CBX2) expression and promote PDAC cell proliferation, migration, and invasion in PADC [51]. Nevertheless, CBX2 exerts biological functions by activating the PI3K/Akt signaling pathway in tumorigenesis [96]. Taken together, PCAT6 boosts the PI3K/Akt/mTOR signaling pathway. 


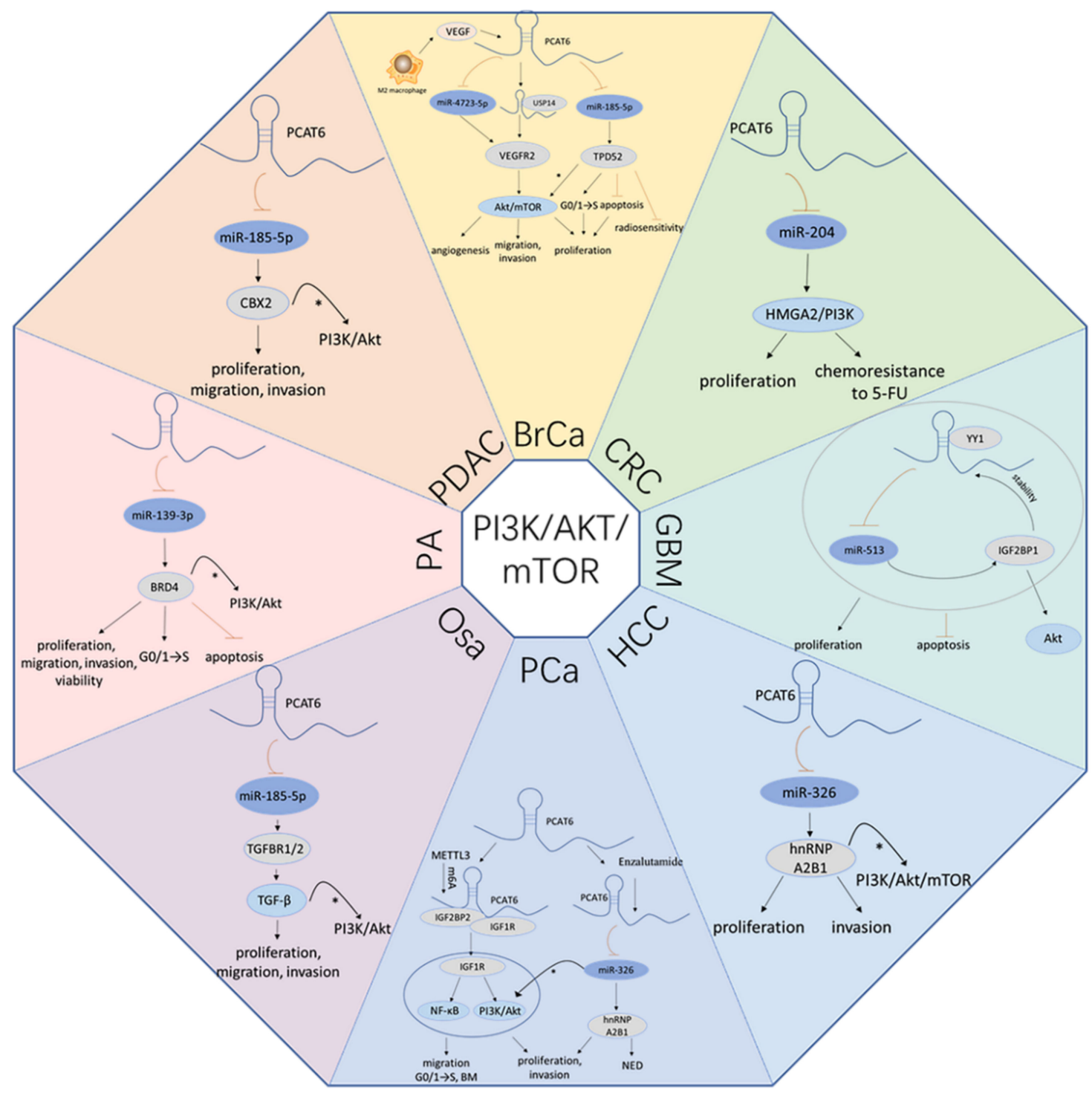

Figure 2. PCAT6 promotes PI3K/AKT/mTOR signaling Pathway. By sponging miRNAs, PCAT6 affects the $\mathrm{PI} 3 \mathrm{~K} / \mathrm{AKT} / \mathrm{mTOR}$ signaling pathway in multiple, cancers, including BrCa, CRC, GBM, HCC, PCa, Osa, PA, PDAC. *: PCAT6 is likely to activate the PI3K/AKT/mTOR signaling by regulating ceRNA mechanisms.

\subsection{PCAT6 Promotes the Wnt//-Catenin Signaling Pathway}

The Wnt signaling pathway plays an indispensable role in embryonic development and stem cell regulation. Therefore, dysregulated Wnt signaling activity leads to a variety of serious diseases, including cancers [97,98]. Deregulation of Wnt signaling is correlated with tumor growth, metastasis, and chemoresistance, ultimately resulting in poor prognosis of patients [99,100]. As shown in Figure 3, TPD52, HNRNPA2B1, BRD4, and CBX2, which may participate in the PI3K/Akt/mTOR pathway by the ceRNA mechanism, have also been found to be related to Wnt signaling [101-108]. PCAT6 activates Wnt/ $\beta$-catenin signaling and promotes GIST cell proliferation, maintaining stemness, and hampering GIST cell apoptosis. Meanwhile, PCAT6 upregulates the expression level of peroxiredoxin (PRDX5) by acting as a ceRNA for miR-143-3p, while downregulation of PCAT6 will hinder GIST cell proliferation and stemness and promote cell apoptosis. The inhibition miR-143-3p or the accumulation of PRDX5 counteract the suppressive effects of loss of PCAT6, indicating that PCAT6 mediates GIST cell proliferation, stemness, and apoptosis through the miR-143-3p/PRDX5 axis [32]. Additionally, it has been revealed that PRDX5 
influences cellular biological behavior by activating the Wnt/ $\beta$-catenin pathway [109], which suggests that PCAT6 can activate the Wnt/ $\beta$-catenin pathway through. the ceRNA network of PRDX5. Dong et al. discovered that PCAT6 excited Wnt/ $\beta$-catenin and RB/E2F signaling by targeting miR-15a in GC. Decreased expression of PCAT6 represses GC cell proliferation and accelerates cell apoptosis, whereas a miR-15a inhibitor reverses the performance [33]. Su et al. found that sevoflurane inhibited LC cell proliferation, migration, and invasion, conversely accelerating cell apoptosis, and inactivated the Wnt/ $\beta$-catenin pathway. However, PCAT6 abolishes the effects of sevoflurane on cell biology function. Analogously, miR-326, acting as a ceRNA for PCAT6, also rescues the effects of PCAT6 on sevoflurane-treated cells. Furthermore, Wnt5a, a downstream target of miR-326, restores the regulatory role of miR-326 in LC cells. Hence, sevoflurane inhibits the PCAT6 that absorbs miR-326, further downregulates Wnt5a, deactivates Wnt/ $\beta$-catenin signaling, and impairs LC cell biology function [42].

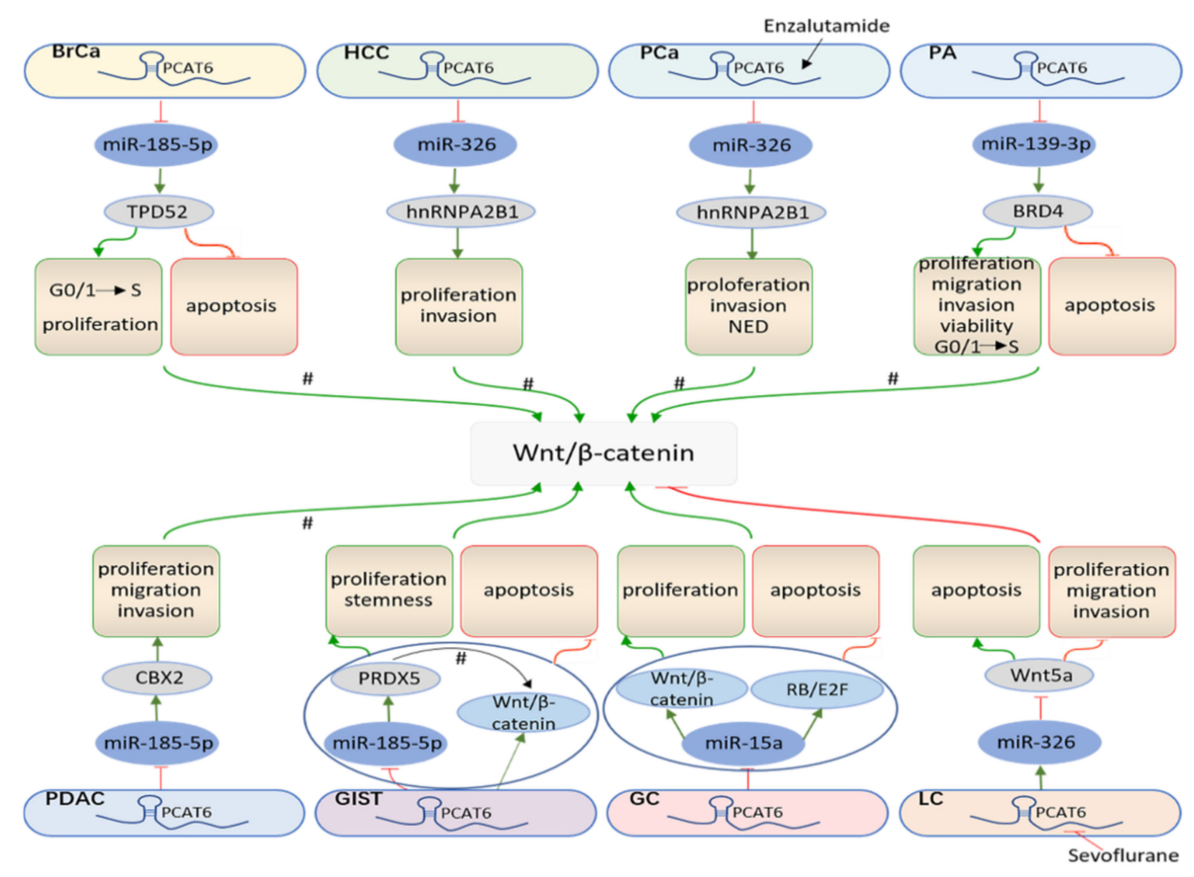

Figure 3. PCAT6 accelerates the Wnt/ $\beta$-catenin signaling pathway. By sponging miRNAs, PCAT6 affects the Wnt/ $\beta$-catenin signaling pathway in various cancers, including BrCa, HCC, Pca, PA, PDAC, GIST, GC, LC. \#: PCAT6 is likely to activate Wnt/ $\beta$-catenin signaling by absorbing miRNAs.

\subsection{PCAT6 Facilitates the EMT Process}

The epithelial-to-mesenchymal transition (EMT), an indispensable cellular program, exerts a specific role in embryonic development and tissue homeostasis. The EMT process is activated by wound healing, fibrosis, and tumors. The EMT process, which is aberrantly induced by cancer cells, enhances cell metastatic and invasive capacity [110-113]. Acting as a sponge for miR-4723-5p in TNBC, PCAT6 upregulates the VEGFR2/Akt/mTOR signaling pathway, leading to significantly decreased E-cadherin expression and significantly increased N-cadherin, Slug, and Twist expression (Figure 4). Hence, PCAT6 enhances cell migration and invasion by partly accelerating the transformation of the EMT process [26]. It has been revealed that PCAT6 upregulates makorin ring finger protein 3 (MKRN3) by endogenously competing with miR-30 in GC. The introduction of PCAT6 impairs the protein expression of caspase-3, caspase-9, Bax, and E-cadherin, and promotes the expression of Bcl-2, N-cadherin, Vimentin, zinc finger E-box binding homeobox 1 (ZEB1), and Snail, which validates the indication that PCAT6 facilitates the GC cell EMT process and hampers apoptosis via the miR-30/MKRN3 axis [34]. Similarly, Dong et al. also found that PCAT6 decreased GC cell apoptosis and EMT by endogenously competing with miR-15a. Defi- 
ciency of PCAT6 promotes apoptosis by conspicuously restraining the Cyclin D1 protein level and enhancing the protein levels of p53, Bax, and cleaved caspase- 3 . The silence of PCAT6 impedes cell EMT process by decreasing the expression of $\mathrm{N}$-cadherin, Vimentin, Snail, and ZEB1 except for E-cadherin [33]. This evidence proves that PCAT6 induces the EMT process by the ceRNA mechanism in GC. Moreover, the results of a subcutaneous xenotransplanted PA mice model have demonstrated that PCAT6 knockdown and miR139-3p overexpression can induce the increase of the E-cadherin protein level and the decrease of the N-cadherin level in tumor tissues. The inhibition of miR-139-3p reverses its suppressive effect and decrease of PCAT6 on the PA cell EMT process in vitro [50]. ZEB1, as a transcriptional regulator, has been confirmed to be involved in the EMT process [114]. It also have observed that lncRNAs affect the EMT process by regulating the miRNAs/ZEB1 axis $[115,116]$. In CC, PCAT6 promotes cell proliferation and metastasis in vitro, and tumor growth in vivo through the miR-543/ZEB1 axis [29]. In addition, PCAT6 also upregulates the ZEB1 level by absorbing miR-143-3p in Osa, promoting cell proliferation, migration, invasion, and cell cycle in vitro, and tumor growth in vivo [44]. Hence, PCAT6 participates in the EMT process by regulating the miRNAs/ZEB1 axis and further influences cell migration and invasion. Moreover, PCAT6 also targets miR-143-3p to activate TGF- $\beta$ activated kinase 1 (TAK1) in OvCa, and then accelerates cell proliferation and enhances cell metastasis [48]. Previously, TAK1 has been reported to induce the EMT process in various diseases $[117,118]$. Therefore, these results confirm that PCAT6 regulates the EMT process by acting as a ceRNA for miRNAs.

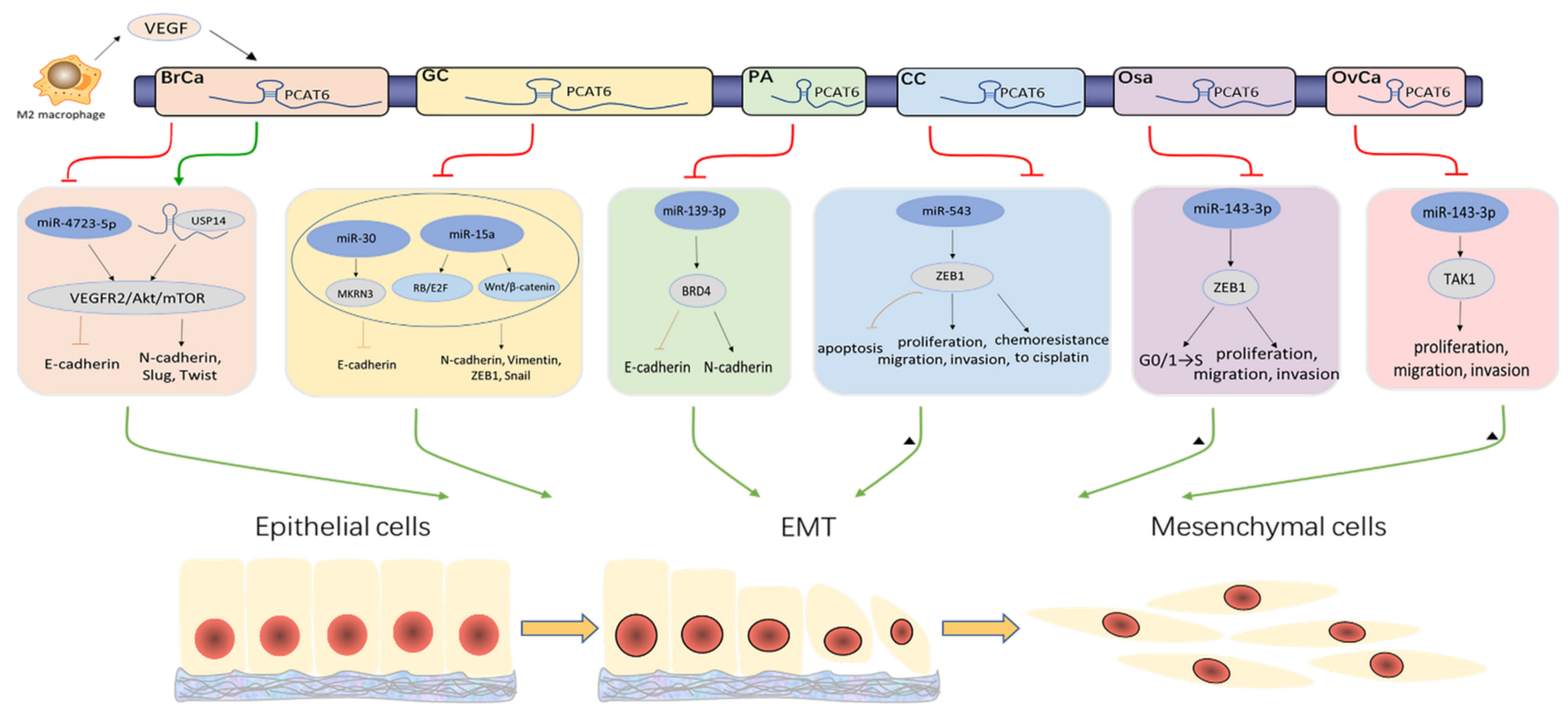

Figure 4. PCAT6 expedites the EMT process. By sponging miRNAs, PCAT6 promotes the EMT process in multiple cancers, including BrCa, GC, PA, CC, Osa, OvCa. $\mathbf{\Delta}$ : PCAT6 is likely to promote the EMT process by absorbing miRNAs.

\subsection{PCAT6 Leads to Radioresistance and Chemoresistance}

Currently, radiotherapy remains the preferred therapy for many cancers. However, many patients who are resistant to radiation have poor prognosis, with cancer recurrence and attenuating radiotherapy effectiveness [119]. Hence, the radiosensitivity of patients is the key to radiotherapy for malignant tumors. Radioresistance is a complex process involving various molecular mechanisms [120]. Recently, increasing amounts of evidence have demonstrated that many lncRNAs are closely associated with radiotherapies, including RBM5-AS1 [121], HOTAIR [122], and PVT1 [123]. Shi et al. also found that there was a relationship between PCAT6 and radioresistance in TNBC. The interference of PCAT6, up-regulation of miR-185-5p, or inhibition of TPD52 enhances the radiosensitivity of TNBC 
cells, inhibits cell proliferation, arrests the cell cycle in the $\mathrm{G}_{0} / \mathrm{G}_{1}$ phase, and accelerates cell apoptosis (Figure 2) [27].

Chemotherapy is an effective anticancer treatment. However, patients can also develop resistance to drug treatment like radioresistance, leading to a dismal prognosis $[124,125]$. Chemoresistance is influenced by tumor properties, biological behavior, and microenvironments [126]. To date, many drugs have been used in chemotherapy, such as platinum, paclitaxel, and 5-fluorouracil (5-FU). Exploring new mechanisms of chemotherapeutic drugs to overcome chemoresistance is urgently needed. Recently, lncRNA dysregulation has been associated with drug resistance, including UCA1 [127], CYTOR [128], and TINCR [129]. Furthermore, the aberrant expression of PCAT6 was also verified to be related to chemoresistance in cancers. It has been demonstrated that both the intervention of PCAT6 and the introduction of miR-543 impair CC cell chemoresistance to cisplatin. Moreover, PCAT6 rescues the suppressive effect of miR-543 on cell chemoresistance [29]. ZEB1, with significant negative correlation with miR-543 and with positive correlation with PCAT6, was confirmed to be a downstream target of miR-543 [29]. Furthermore, the overexpression of ZEB1 partially counteracts the inhibitory effect of PCAT6 downregulation on cell chemoresistance to cisplatin (Figure 4) [29]. Wu et al. found that loss of PCAT6 reversed the chemoresistance of CRC cells to 5-fluorouracil (5-FU), while this performance could be partially abrogated by depression of miR-204. Moreover, PCAT6 activates HMGA2/PI3K signaling by absorbing miR-204, thus reducing the CRC cells' chemosensitivity to 5-FU (Figure 2) [31]. Consequently, PCAT6 may be a new effective target for treatment in cancer patients undergoing clinical radiotherapy and chemotherapy resistance.

\subsection{Other ceRNA Mechanisms of PCAT6}

In addition to those mentioned above, it has been elucited that PCAT6 boosts cancer progress via various signal pathways. PCAT6 can act as a sponge for miR-513a to facilitate $\mathrm{BC}$ progression. The inhibition of miR-513a partially offsets the proliferation, migration, and invasion induced by the knockdown of PCAT6 [21]. Moreover, PCAT6 promotes cell proliferation, migration, and invasion by inhibiting miR-143-3p and upregulating protein disulfide isomerase familyA mumber 6 (PDIA6), in BC [25]. In NSCLC PCAT6 absorbs miR-330-5p and promotes cell proliferation, migration, invasion in vitro, and tumor growth in vivo [39]. PCAT6 has also been found to have a competitive binding relationship with miR-330-5p, which in turn induced CCA cell proliferation and invasion [49].

Furthermore, increasing evidence has indicated that dozens of lncRNAs are associated with immune cell function. For instance, XIST [130] and SBF2-AS1 [131] can the induce M2 polarization of tumor-associated macrophages, which are indispensable cells within the tumor immune microenvironment. Similarly, Tu et al. validated that PCAT6 overexpression induced the M2 polarization of macrophages deriving from CCA patients, and indicated the effect could be reversed by miR-326. Simultaneously, miR-326 mimics can abolish the promoting impacts of PCAT6 introduction on macrophage cellular reactive oxygen species production and mitochondrial and metabolic dysfunction. Furthermore, RhoA has been confirmed to be a downstream target of miR-326, which further activates the RhoA-ROCK signaling pathway and promotes tumor progression. The results of animal experiments uncovered that depletion of PCAT6 inhibited tumor growth by activating the $\mathrm{T}$ cell response in vivo, which was mainly manifested by the increase of $\mathrm{CD}^{+} \mathrm{T}$ cells and IFN- $\gamma$-producing $\mathrm{CD}^{+}{ }^{+} \mathrm{T}$ and $\mathrm{CD} 8^{+} \mathrm{T}$ cells. These findings suggest that $P C A T 6$ may serve as a potential immune-therapeutic target for CCA (Figure 5) [54]. 


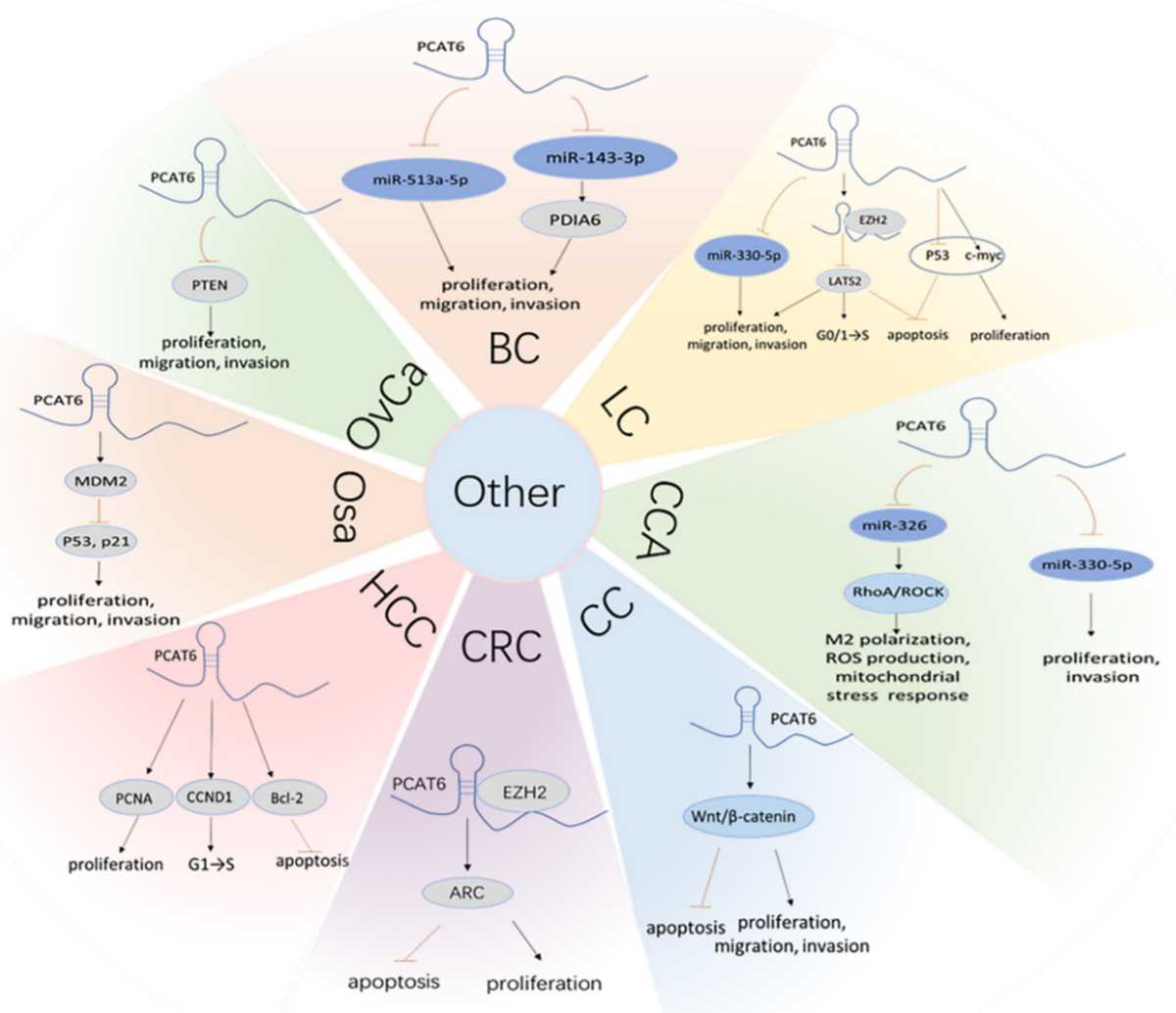

Figure 5. PCAT6 exerts biological behaviors by other ceRNA and beyond ceRNA mechanisms in various cancers, including BC, LC, CCA, CC, CRC, HCC, Osa, OvCa.

\section{The Mechanisms of PCAT6 above ceRNA}

In addition to absorbing miR-4723-5p, PCAT6 also activates the VEFGR2/Akt/mTOR axis by recruiting USP14 to stabilize VEGFR2 and further elicits biological functions in vitro and in vivo in BrCa (Figure 2) [26]. TOP/FOP flash reporter assays have revealed that silence of PCAT6 inactivates Wnt/ $\beta$-catenin signaling pathway in CC. Meanwhile, the results from real-time fluorescence quantitative PCR (qRT-PCR) and Western blot analyses indicate that several pivotal genes of Wnt $/ \beta$-catenin signaling (e.g., $\beta$-catenin, cyclin D1, and c-myc), are remarkably suppressed in CC cells transfected with siRNA targeting for PCAT6 [28]. PCAT6 upregulates the activity regulated cytoskeleton associated protein (ARC) via binding to EZH2 in CRC. It also impedes cell apoptosis and promotes cell proliferation [30]. In HCC, PCAT6 promotes cell proliferation, increases the proportion of the $S$ phase, and decreases cell apoptosis. In addition, PCAT6 also affects the expression of the protein related to the proliferation, cycle, and apoptosis, including proliferating cell nuclear antigen (PCNA), cyclin D1 (CCND1), and B-cell lymphoma-2 (Bcl-2) [37]. Bioinformatics analyses indicate that PCAT6 may be associated with Wnt, HIF-1, and metabolic pathways. Also, it may correlate with p53 and participate in the apoptotic signaling pathways [37]. PCAT6 indirectly regulates c-myc and p53 genes to affect Bcl-2 and Bax expressions, which further prevent sLC cell early apoptosis and induce cell proliferation [20]. Moreover, in NSCLC, PCAT6 transcriptionally impairs large tumor suppressor kinase 2 (LATS2) promoter activity by binding to EZH2, which mediates $\mathrm{H} 3 \mathrm{~K} 27$ trimethylation and accelerates the cell cycle, promoting cell proliferation, tumor growth and metastasis, and hindering cell apoptosis [40]. In Osa, overexpression of PCAT6 enhances cell proliferation, migration, and invasion in vitro, and tumor growth in vivo, while depression of MDM2 proto-oncogene (MDM2) exerts an opposite influence. Moreover, upregulation of PCAT6 decreases p53 and p21 expression, and further induces tumorgenesis [46]. However, this performance 
is rescued by the depletion of MDM2 [46]. In OvCa, PCAT6 increases the capacity of cell proliferation and metastasis by decreasing the phosphatase and tensin homolog (PTEN) level. Moreover, both the mRNA and protein levels of PTEN are upregulated by depleting PCAT6. Meanwhile, knockdown of PTEN rescues the inhibition of the metastatic capability of OvCa cells induced by PCAT6 suppression (Figure 5) [47]. Lang et al. discovered that PCAT6 upregulating by methyltransferase 3 (METTL3), a catalytic subunit of the N6-adenosine-methyltransferase complex that induces $\mathrm{m}^{6} \mathrm{~A}$ modification, promoted $\mathrm{PCa}$ cell proliferation and metastasis in vitro, and accelerated tumor growth and bone metastasis (BM) in vivo. Upregulation of PCAT6 can interact with insulin like growth factor 2 mRNA binding protein 2 (IGF2BP2) and insulin like growth factor 1 receptor (IGF1R) to stabilize IGF1R mRNA and activate the downstream signaling pathways, including PI3K/Akt signaling and NF- $\mathrm{KB}$ signaling, which ultimately facilitate tumor growth and BM (Figure 2) [53].

\section{The Diagnostic and Prognostic Value of PCAT6 Overexpression}

Various studies have shown that high expression of PCAT6 in multiple cancers is associated with various clinicopathologic features, mainly including larger tumor size, high tumor differentiation, advanced tumor stage, more tissues metastasis, and so on (Table 2), Some researchers have estimated the diagnostic and prognostic values of upregulated PCAT6 in cancers (Table 3). Zhang et al. found that the area under the curve (AUC) of the serum PCAT6 level was greater than 0.8 , which could distinguish $B C$ patients from the normal controls. It has been further demonstrated that the serum PCAT6 level is suitable as a BC diagnosis biomarker [24]. Wan et al. revealed that the tissue PCAT6 level had great diagnostic values, including AUC greater than 0.9 , with higher sensitivity $(86.67-100 \%)$ and higher specificity (78.57-96\%) in 349 cases of NSCLC from five GEO datasets (GSE19804, GSE18842, GSE30219, GSE19188, and GSE27262). Meanwhile, they also had noticed that the AUCs of plasma PCAT6 were 0.9213 (sensitivity, $87.67 \%$; specificity, $97.44 \%$ ) in lung adenocarcinoma (LUAD) and 0.9583 (sensitivity, $94.12 \%$; specificity, $100 \%$ ) in lung squamous cell carcinoma (LUSC), respectively [41]. These results suggest that PCAT6 may be a promising diagnostic biomarker for BC and LC.

In addition, more studies have found that the accumulation of PCAT6 is closely related to the prognosis of various tumor patients. It has been illustrated that the PCAT6 level is negatively correlated to the ovarall survival (OS) of patients with CRC [30], GC [34], LC [20,40,43], and PDAC [51]. Furthermore, increased expression of PCAT6 reduces OS and progression-free survival (PFS) in BC [21,24] and Osa [44,45] patients. Lv et al. conducted Kaplan-Meier survival analysis to investigate the association between PCAT6 level and postoperative survival in patients with CC. They found that a high level of PCAT6 predicts poor OS and disease-free survival (DFS) in patients. Subsequently, univariate analysis and multivariate analysis also have revealed that high expression of PCAT6 is an independent poor prognostic factor for both OS and DFS in CC [28]. For HCC, many reports have revealed that upregulated PCAT6 is associated with shorter OS, PFS, and DFS [36-38,132]. Similarly, Kaplan-Meier Plotter analyses have demonstrated that high expression of PCAT6 can be used as a prognostic biomarker for OS, PFS, and post-progression survival (PPS) in OvCa patients [48]. In PCa patients with BM, patients with higher PCAT6 expression have poorer overall and BM-free survivals and shorter DFS [53]. These results have indicated that PCAT6 may be a clinical prognostic factor. 
Table 2. Clinicopathologic features of PCAT6 in multiple human cancers.

\begin{tabular}{|c|c|c|}
\hline Tumor Types & Clinicopathologic Features & Ref. \\
\hline \multirow[t]{2}{*}{ Bladder cancer } & $\begin{array}{l}\text { Larger tumor size, high tumor differentiation, advanced TNM stage, more lymph nodes } \\
\text { metastasis, more distant metastasis }\end{array}$ & [24] \\
\hline & Pathological stage & [21] \\
\hline \multirow{2}{*}{ Breast cancer } & More tissues metastasis, higher tumor stages & [26] \\
\hline & More lymph nodes metastasis, advanced tumor stages & [27] \\
\hline Cervical cancer & Advanced FIGO stage, more lymph nodes metastasis, depth of cervical invasion & [28] \\
\hline \multirow{2}{*}{ Colorectal cancer } & Tumor subtype, $\mathrm{N}$ classification, metastasis, poorer clinical stage & [30] \\
\hline & Larger tumor size, advanced TNM stage, lymph node metastasis & [31] \\
\hline Gastric cancer & Larger tumor size, advanced TNM stage, more metastasis & [34] \\
\hline $\begin{array}{l}\text { Hepatocellular } \\
\text { carcinoma }\end{array}$ & Moderated or poorly differentiation, advanced TNM stage & [37] \\
\hline \multirow{5}{*}{ Lung cancer } & Advanced TNM stage, more metastasis & [41] \\
\hline & Advanced TNM stage, more metastasis & [39] \\
\hline & Larger tumor size, more lymph node metastasis, advanced TNM stage & [40] \\
\hline & Larger tumor size, more lymph node metastasis, advanced TNM stage & [20] \\
\hline & Larger tumor size, more metastasis, advanced TNM stage & [43] \\
\hline \multirow{2}{*}{ Osteosarcoma } & Larger tumor size, more metastasis, advanced TNM stage & [44] \\
\hline & Larger tumor size, more metastasis, advanced TNM stage & [45] \\
\hline \multirow{2}{*}{ Ovarian cancer } & More lymph node metastasis, more distant metastasis & [47] \\
\hline & Advanced TNM stage & [48] \\
\hline Cholangiocarcinoma & Advanced TNM stage & [49] \\
\hline $\begin{array}{l}\text { Pancreatic ductal } \\
\text { adenocarcinoma }\end{array}$ & Advanced TNM stage, more lymph node invasion & [51] \\
\hline Prostate cancer & Poor differentiation, higher serum PSA, advanced gleason grade, more BM & [53] \\
\hline
\end{tabular}

TNM, tumor node metastasis; FIGO, Federation of Gynecology and Obstetrics; PSA, prostate specific antigen; BM, bone metastasis.

Table 3. Diagnostic or prognostic value of PCAT6.

\begin{tabular}{|c|c|c|c|}
\hline Tumor Types & Expression & Diagnostic or Prognostic Value & Ref. \\
\hline \multirow{2}{*}{ Bladder cancer } & $\mathrm{Up}$ & Poor OS, and poor PFS, AUC > 0.8 & [24] \\
\hline & Up & Poor OS & [21] \\
\hline Cervical cancer & $\mathrm{Up}$ & Shorter OS and DFS & [28] \\
\hline \multirow{2}{*}{ Colorectal cancer } & Up & Worse OS & [30] \\
\hline & Up & Poor OS & [31] \\
\hline Gastric cancer & Up & Worse prognosis & [34] \\
\hline \multirow{4}{*}{$\begin{array}{l}\text { Hepatocellular } \\
\text { carcinoma }\end{array}$} & $\mathrm{Up}$ & Poor OS & [36] \\
\hline & Up & Poor OS and DFS & [37] \\
\hline & Up & Shorter OS & [38] \\
\hline & Up & Poor PFS & [132] \\
\hline \multirow{3}{*}{ Lung cancer } & Up & $\begin{array}{l}\text { Tissue PCAT6: AUC > 0.9, sensitivity } 86.67-100 \% \text {, specificity } 78.57-96 \% \text { Plasma } \\
\text { PCAT6: a. LUAD: AUC }=0.9213 \text {, sensitivity } 87.67 \% \text {, specificity } 97.44 \text {; b. LUSC: } \\
\text { AUC }=0.9583 \text {, sensitivity } 94.12 \% \text {, specificity } 100 \%\end{array}$ & [41] \\
\hline & Up & Poor OS & [40] \\
\hline & $\mathrm{Up}$ & Poor OS & [20] \\
\hline
\end{tabular}


Table 3. Cont.

\begin{tabular}{cccc}
\hline Tumor Types & Expression & Diagnostic or Prognostic Value & Ref. \\
\hline & $\mathrm{Up}$ & Poor OS & Shorter OS and PFS \\
\hline \multirow{2}{*}{ Osteosarcoma } & $\mathrm{Up}$ & Shorter OS and PFS & [43] \\
\cline { 2 - 4 } & $\mathrm{Up}$ & Poor OS, PFS and PPS & [44] \\
\hline Ovarian cancer & $\mathrm{Up}$ & Worse OS & {$[48]$} \\
\hline $\begin{array}{l}\text { Pancreatic ductal } \\
\text { adenocarcinoma }\end{array}$ & $\mathrm{Up}$ & Shorter overall and BM-free survival, shorter DFS & {$[53]$} \\
\hline Prostate cancer & $\mathrm{Up}$ &
\end{tabular}

OS, overall survival; PFS, progression-free survival; AUC, area under curve; DFS, disease-free survival; PPS, post progression survival.

\section{Discussion and Perspectives}

In conclusion, LncRNA PCAT6, a vital oncogene, is first found overexpressed in lung cancer [20], and subsequently verified in multiple human cancers. It has been proven to be a promising diagnostic biomarker and clinical prognostic factor in different diseases (Table 3). The accumulation of PCAT6 is closely related to many clinicopathological features (Table 2). Furthermore, PCAT6 overexpression promotes tumor cell proliferation [21], migration [44], invasion [45], chemoresistance [29,31], and radioresistance [27]. These processes involve various signaling pathways, including PI3K/Akt/mTOR signaling, Wnt/ $\beta$-catenin signaling, signaling, and RhoA-ROCK signaling. It has been confirmed that these pathways play indispensable roles in tumorigenesis and disease progression [133-136]. However, PCAT6 can regulate the signaling pathways through ceRNA [26] and other mechanisms [28]. Hence, $P C A T 6$, as a promising diagnostic biomarker, may be a checkpoint target for precision therapy in human cancers.

Author Contributions: F.J. wrote the original draft. Q.S., Q.L., C.H., Z.L., H.W. (Haojie Wu), S.G., H.W. (Hui Wang), Y.Z. gave suggestions about the molecular mechanisms of PCAT6 and summarized relevant studies. Q.S. and Y.Z. helped organize and revise the manuscript. Q.S. and H.W. (Hui Wang) are the funding recipients. All authors contributed to the article and approved the submitted version. All authors have read and agreed to the published version of the manuscript.

Funding: This work is funded by Q.S. (Grant No. 82071738, 81671541, 81701545, 81273202), the Medical Leadership Program of Jiangsu College of Nursing (2021001), and Y.Z. (Grant No. 82100183). The APC is funded by Q.S.

Acknowledgments: We would like to thank Weili Cai for previewing the manuscript and giving suggestion for revising the manuscript.

Conflicts of Interest: The authors declare no conflict of interest.

\section{References}

1. Akhade, V.; Pal, D.; Kanduri, C. Long noncoding RNA: Genome organization and mechanism of action. Adv. Exp. Med. Biol. 2017, 1008, 47-74. [CrossRef]

2. Ye, M.; Zhang, J.; Wei, M.; Liu, B.; Dong, K. Emerging role of long noncoding RNA-encoded micropeptides in cancer. Cancer Cell Int. 2020, 20, 506. [CrossRef]

3. Boland, R.C. Non-coding RNA: It's not junk. Dig. Dis. Sci. 2017, 62, 1107-1109. [CrossRef]

4. Kopp, F.; Mendell, J. Functional classification and experimental dissection of long noncoding RNAs. Cell 2018, 172, $393-407$. [CrossRef]

5. Wong, N.; Huang, C.; Islam, R.; Yip, S. Long non-coding RNAs in hematological malignancies: Translating basic techniques into diagnostic and therapeutic strategies. J. Hematol. Oncol. 2018, 11, 131. [CrossRef] [PubMed]

6. Ransohoff, J.; Wei, Y.; Khavari, P. The functions and unique features of long intergenic non-coding RNA. Nat. Rev. Mol. Cell Biol. 2018, 19, 143-157. [CrossRef]

7. Adams, B.; Parsons, C.; Walker, L.; Zhang, W.; Slack, F. Targeting noncoding RNAs in disease. J. Clin. Investig. 2017, 127, 761-771. [CrossRef] [PubMed]

8. Wu, P.; Mo, Y.; Peng, M.; Tang, T.; Zhong, Y.; Deng, X.; Xiong, F.; Guo, C.; Wu, X.; Li, Y.; et al. Emerging role of tumor-related functional peptides encoded by lncRNA and circRNA. Mol. Cancer 2020, 19, 22. [CrossRef] [PubMed] 
9. Xie, Y.; Dang, W.; Zhang, S.; Yue, W.; Yang, L.; Zhai, X.; Yan, Q.; Lu, J. The role of exosomal noncoding RNAs in cancer. Mol. Cancer 2019, 18, 37. [CrossRef] [PubMed]

10. Huarte, M. The emerging role of lncRNAs in cancer. Nat. Med. 2015, 21, 1253-1261. [CrossRef]

11. Luo, Y.; Fang, Z.; Ling, Y.; Luo, W. LncRNA-H19 acts as a ceRNA to regulate HE4 expression by sponging miR-140 in human umbilical vein endothelial cells under hyperglycemia with or without $\alpha$-Mangostin. Biomed. Pharmacother. 2019, 118, 109256. [CrossRef]

12. Zhao, L.; Zhou, Y.; Zhao, Y.; Li, Q.; Zhou, J.; Mao, Y. Long non-coding RNA TUSC8 inhibits breast cancer growth and metastasis via miR-190b-5p/MYLIP axis. Aging 2020, 12, 2974-2991. [CrossRef]

13. Wang, W.; Zhou, R.; Wu, Y.; Liu, Y.; Su, W.; Xiong, W.; Zeng, Z. PVT1 Promotes Cancer Progression via MicroRNAs. Front. Oncol. 2019, 9, 609. [CrossRef] [PubMed]

14. Wen, S.; Qin, Y.; Wang, R.; Yang, L.; Zeng, H.; Zhu, P.; Li, Q.; Qiu, Y.; Chen, S.; Liu, Y.; et al. A novel Lnc408 maintains breast cancer stem cell stemness by recruiting SP3 to suppress CBY1 transcription and increasing nuclear $\beta$-catenin levels. Cell Death Dis. 2021, 12, 437. [CrossRef]

15. Wang, X.; Zhang, X.; Dang, Y.; Li, D.; Lu, G.; Chan, W.; Leung, P.; Zhao, S.; Qin, Y.; Chen, Z. Long noncoding RNA HCP5 participates in premature ovarian insufficiency by transcriptionally regulating MSH5 and DNA damage repair via YB1. Nucleic Acids Res. 2020, 48, 4480-4491. [CrossRef] [PubMed]

16. Prensner, J.; Zhao, S.; Erho, N.; Schipper, M.; Iyer, M.; Dhanasekaran, S.; Magi-Galluzzi, C.; Mehra, R.; Sahu, A.; Siddiqui, J.; et al RNA biomarkers associated with metastatic progression in prostate cancer: A multi-institutional high-throughput analysis of SChLAP1. Lancet. Oncol. 2014, 15, 1469-1480. [CrossRef]

17. Qu, L.; Wang, Z.; Chen, Q.; Li, Y.; He, H.; Hsieh, J.; Xue, S.; Wu, Z.; Liu, B.; Tang, H.; et al. Prognostic Value of a Long Non-coding RNA Signature in Localized Clear Cell Renal Cell Carcinoma. Eur. Urol. 2018, 74, 756-763. [CrossRef]

18. Tong, J.; Ma, X.; Yu, H.; Yang, J. SNHG15: A promising cancer-related long noncoding RNA. Cancer Manag. Res. 2019, 11, 5961-5969. [CrossRef] [PubMed]

19. Bhan, A.; Soleimani, M.; Mandal, S. Long Noncoding RNA and Cancer: A New Paradigm. Cancer Res. 2017, 77, 3965-3981. [CrossRef]

20. Wan, L.; Zhang, L.; Fan, K.; Cheng, Z.; Sun, Q.; Wang, J. Knockdown of Long Noncoding RNA PCAT6 inhibits proliferation and invasion in lung cancer cells. Oncol. Res. 2016, 24, 161-170. [CrossRef]

21. Xia, W.; Chen, C.; Zhang, M.; Zhu, L. LncRNA PCAT6 aggravates the progression of bladder cancer cells by targeting miR-513a-5p. Eur. Rev. Med Pharmacol. Sci. 2020, 24, 9908-9914. [CrossRef]

22. Ørom, U.; Derrien, T.; Beringer, M.; Gumireddy, K.; Gardini, A.; Bussotti, G.; Lai, F.; Zytnicki, M.; Notredame, C.; Huang, Q.; et al. Long noncoding RNAs with enhancer-like function in human cells. Cell 2010, 143, 46-58. [CrossRef]

23. Fagerberg, L.; Hallström, B.; Oksvold, P.; Kampf, C.; Djureinovic, D.; Odeberg, J.; Habuka, M.; Tahmasebpoor, S.; Danielsson, A.; Edlund, K.; et al. Analysis of the human tissue-specific expression by genome-wide integration of transcriptomics and antibody-based proteomics. Mol. Cell. Proteom. MCP 2014, 13, 397-406. [CrossRef] [PubMed]

24. Zhang, D.; Du, D.; Yi, S.; Li, X. LncRNA PCAT6: A potential biomarker for diagnosis and prognosis of bladder cancer. Ann. Diagn. Pathol. 2020, 49, 151642. [CrossRef] [PubMed]

25. Zhang, Y.; Chen, L.; Luo, G. Long non-coding RNA PCAT6 regulates bladder cancer progression via the microRNA-143-3p/PDIA6 axis. Exp. Ther. Med. 2021, 22, 947. [CrossRef]

26. Dong, F.; Ruan, S.; Wang, J.; Xia, Y.; Le, K.; Xiao, X.; Hu, T.; Wang, Q. M2 macrophage-induced lncRNA PCAT6 facilitates tumorigenesis and angiogenesis of triple-negative breast cancer through modulation of VEGFR2. Cell Death Dis. 2020, 11, 728. [CrossRef] [PubMed]

27. Shi, R.; Wu, P.; Liu, M.; Chen, B.; Cong, L. Knockdown of lncRNA PCAT6 enhances radiosensitivity in triple-negative breast cancer cells by regulating miR-185-5p/TPD52 axis. OncoTargets Ther. 2020, 13, 3025-3037. [CrossRef]

28. Lv, X.; Tang, Q.; Tu, Y.; Yan, D.; Wei, Q. Long noncoding RNA PCAT6 regulates cell growth and metastasis via Wnt/ $\beta$-catenin pathway and is a prognosis marker in cervical cancer. Eur. Rev. Med Pharmacol. Sci. 2019, 23, 1947-1956. [CrossRef]

29. Ma, Z.; Gu, G.; Pan, W.; Chen, X. LncRNA PCAT6 Accelerates the Progression and Chemoresistance of Cervical Cancer Through Up-Regulating ZEB1 by Sponging miR-543. OncoTargets Ther. 2020, 13, 1159-1170. [CrossRef] [PubMed]

30. Huang, W.; Su, G.; Huang, X.; Zou, A.; Wu, J.; Yang, Y.; Zhu, Y.; Liang, S.; Li, D.; Ma, F.; et al. Long noncoding RNA PCAT6 inhibits colon cancer cell apoptosis by regulating anti-apoptotic protein ARC expression via EZH2. Cell Cycle 2019, 18, 69-83. [CrossRef]

31. Wu, H.; Zou, Q.; He, H.; Liang, Y.; Lei, M.; Zhou, Q.; Fan, D.; Shen, L. Long non-coding RNA PCAT6 targets miR-204 to modulate the chemoresistance of colorectal cancer cells to 5-fluorouracil-based treatment through HMGA2 signaling. Cancer Med. 2019, 8, 2484-2495. [CrossRef] [PubMed]

32. Bai, F.; Zhang, N.; Fang, W.; He, X.; Zheng, Y.; Gu, D. PCAT6 mediates cellular biological functions in gastrointestinal stromal tumor via upregulation of PRDX5 and activation of Wnt pathway. Mol. Carcinog. 2020, 59, 661-669. [CrossRef]

33. Dong, D.; Lun, Y.; Sun, B.; Sun, H.; Wang, Q.; Yuan, G.; Quan, J. Silencing of long non-coding RNA PCAT6 restrains gastric cancer cell proliferation and epithelial-mesenchymal transition by targeting microRNA-15a. Gen. Physiol. Biophys. 2020, $39,1-12$. [CrossRef] 
34. Xu, Y.; Sun, J.; Jin, Y.; Yu, H. PCAT6 participates in the development of gastric cancer through endogenously competition with microRNA-30. Eur. Rev. Med Pharmacol. Sci. 2018, 22, 5206-5213. [CrossRef] [PubMed]

35. Liu, P.; Zhao, P.; Li, B.; Xu, D.; Wang, K. LncRNA PCAT6 Regulated by YY1 Accelerates the Progression of Glioblastoma via miR-513/IGF2BP1. Neurochem. Res. 2020, 45, 2894-2902. [CrossRef]

36. Chen, S.; Chen, Y.; Qian, Q.; Wang, X.; Chang, Y.; Ju, S.; Xu, Y.; Zhang, C.; Qin, N.; Ding, H.; et al. Gene amplification derived a cancer-testis long noncoding RNA PCAT6 regulates cell proliferation and migration in hepatocellular carcinoma. Cancer Med. 2019, 8, 3017-3025. [CrossRef]

37. Luo, Y.; Lin, J.; Zhang, Y.; Dai, G.; Li, A.; Liu, X. LncRNA PCAT6 predicts poor prognosis in hepatocellular carcinoma and promotes proliferation through the regulation of cell cycle arrest and apoptosis. Cell Biochem. Funct. 2020, 38, 895-904. [CrossRef]

38. Luo, J.; Zheng, J.; Hao, W.; Zeng, H.; Zhang, Z.; Shao, G. lncRNA PCAT6 facilitates cell proliferation and invasion via regulating the miR-326/hnRNPA2B1 axis in liver cancer. Oncol. Lett. 2021, 21, 471. [CrossRef]

39. Cui, L.; Xu, H.; Yang, W.; Yu, L. IncRNA PCAT6 promotes non-small cell lung cancer cell proliferation, migration and invasion through regulating miR-330-5p. OncoTargets Ther. 2018, 11, 7715-7724. [CrossRef] [PubMed]

40. Shi, X.; Liu, Z.; Liu, Z.; Feng, X.; Hua, F.; Hu, X.; Wang, B.; Lu, K.; Nie, F. Long noncoding RNA PCAT6 functions as an oncogene by binding to EZH2 and suppressing LATS2 in non-small-cell lung cancer. EBioMedicine 2018, 37, 177-187. [CrossRef]

41. Wan, L.; Zhang, L.; Fan, K.; Wang, J. Diagnostic significance of circulating long noncoding RNA PCAT6 in patients with non-small cell lung cancer. OncoTargets Ther. 2017, 10, 5695-5702. [CrossRef]

42. Su, G.; Yan, Z.; Deng, M. Sevoflurane Inhibits Proliferation, Invasion, but Enhances Apoptosis of Lung Cancer Cells by Wnt/ $\beta$ catenin Signaling via Regulating lncRNA PCAT6/miR-326 Axis. Open Life Sci. 2020, 15, 159-172. [CrossRef] [PubMed]

43. Lou, B.; Wei, D.; Zhou, X.; Chen, H. Long non-coding RNA KDM5B anti-sense RNA 1 enhances tumor progression in non-small cell lung cancer. J. Clin. Lab. Anal. 2020, 34, e22897. [CrossRef] [PubMed]

44. Wu, K.; Feng, Q.; Li, L.; Xiong, Y.; Liu, S.; Liu, J.; Wu, Q. Long-Noncoding RNA PCAT6 Aggravates Osteosarcoma Tumourigenesis via the MiR-143-3p/ZEB1 Axis. OncoTargets Ther. 2020, 13, 8705-8714. [CrossRef] [PubMed]

45. Zhu, C.; Huang, L.; Xu, F.; Li, P.; Li, P.; Hu, F. LncRNA PCAT6 promotes tumor progression in osteosarcoma via activation of TGF- $\beta$ pathway by sponging miR-185-5p. Biochem. Biophys. Res. Commun. 2020, 521, 463-470. [CrossRef] [PubMed]

46. Guan, X.; Xu, Y.; Zheng, J. Long non-coding RNA PCAT6 promotes the development of osteosarcoma by increasing MDM2 expression. Oncol. Rep. 2020, 44, 2465-2474. [CrossRef] [PubMed]

47. Kong, F.; Lv, Y.; Yao, H.; Zhang, H.; Zhou, Y.; Liu, S. LncRNA PCAT6 promotes occurrence and development of ovarian cancer by inhibiting PTEN. Eur. Rev. Med Pharmacol. Sci. 2019, 23, 8230-8238. [CrossRef]

48. Tan, X.; Shao, Y.; Teng, Y.; Liu, S.; Li, W.; Xue, L.; Cao, Y.; Sun, C.; Zhang, J.; Han, J.; et al. The Cancer-Testis Long Non-coding RNA PCAT6 Facilitates the Malignant Phenotype of Ovarian Cancer by Sponging miR-143-3p. Front. Cell Dev. Biol. 2021, 9 , 593677. [CrossRef]

49. Xin, Y.; He, X.; Zhao, W.; Zhan, M.; Li, Y.; Xiao, J.; He, K.; Lu, L. LncRNA PCAT6 increased cholangiocarcinoma cell proliferation and invasion via modulating miR-330-5p. Am. J. Transl. Res. 2019, 11, 6185-6195.

50. Zhao, P.; Cheng, J.; Li, B.; Nie, D.; Wang, H.; Li, C.; Gui, S.; Zhang, Y. LncRNA PCAT6 regulates the progression of pituitary adenomas by regulating the miR-139-3p/BRD4 axis. Cancer Cell Int. 2021, 21, 14. [CrossRef]

51. Wang, W.; Li, X.; Guan, C.; Hu, Z.; Zhao, Y.; Li, W.; Jiang, X. LncRNA PCAT6 promotes the proliferation, migration and invasion of pancreatic ductal adenocarcinoma via regulating miR-185-5p/CBX2 axis. Pathol. Res. Pract. 2020, 216, 153074. [CrossRef] [PubMed]

52. Liu, B.; Jiang, H.; Yuan, T.; Luo, J.; Zhou, W.; Jiang, Q.; Wu, D. Enzalutamide-Induced Upregulation of PCAT6 Promotes Prostate Cancer Neuroendocrine Differentiation by Regulating miR-326/HNRNPA2B1 Axis. Front. Oncol. 2021, 11, 650054. [CrossRef]

53. Lang, C.; Yin, C.; Lin, K.; Li, Y.; Yang, Q.; Wu, Z.; Du, H.; Ren, D.; Dai, Y.; Peng, X. m A modification of lncRNA PCAT6 promotes bone metastasis in prostate cancer through IGF2BP2-mediated IGF1R mRNA stabilization. Clin. Transl. Med. 2021, 11, e426. [CrossRef]

54. Tu, J.; Wu, F.; Chen, L.; Zheng, L.; Yang, Y.; Ying, X.; Song, J.; Chen, C.; Hu, X.; Zhao, Z.; et al. viaLong Non-Coding RNA PCAT6 Induces M2 Polarization of Macrophages in Cholangiocarcinoma Modulating miR-326 and RhoA-ROCK Signaling Pathway. Front. Oncol. 2020, 10, 605877. [CrossRef] [PubMed]

55. Acha-Sagredo, A.; Uko, B.; Pantazi, P.; Bediaga, N.; Moschandrea, C.; Rainbow, L.; Marcus, M.; Davies, M.; Field, J.; Liloglou, T. Long non-coding RNA dysregulation is a frequent event in non-small cell lung carcinoma pathogenesis. Br. J. Cancer 2020, 122, 1050-1058. [CrossRef]

56. Bai, Y.; Qu, Y.; Wu, Z.; Ren, Y.; Cheng, Z.; Lu, Y.; Hu, J.; Lou, J.; Zhao, J.; Chen, C.; et al. Absolute quantification and analysis of extracellular vesicle lncRNAs from the peripheral blood of patients with lung cancer based on multi-colour fluorescence chip-based digital PCR. Biosens. Bioelectron. 2019, 142, 111523. [CrossRef]

57. Siddique, H.; Al-Ghafari, A.; Choudhry, H.; AlTurki, S.; Alshaibi, H.; Al Doghaither, H.; Alsufiani, H. Long noncoding RNAs as prognostic markers for colorectal cancer in Saudi patients. Genet. Test. Mol. Biomark. 2019, 23, 509-514. [CrossRef]

58. Chu, C.; Zhang, Q.; da Rocha, S.; Flynn, R.; Bharadwaj, M.; Calabrese, J.; Magnuson, T.; Heard, E.; Chang, H. Systematic discovery of Xist RNA binding proteins. Cell 2015, 161, 404-416. [CrossRef] [PubMed]

59. Li, S.; Zhu, Y.; Li, R.; Huang, J.; You, K.; Yuan, Y.; Zhuang, S. $\alpha$ LncRNA Lnc-APUE is Repressed by HNF4 and Promotes G1/S Phase Transition and Tumor Growth by Regulating MiR-20b/E2F1 Axis. Adv. Sci. 2021, 8, 2003094. [CrossRef] 
60. Yin, G.; Peng, Y.; Lin, Y.; Wang, P.; Li, Z.; Wang, R.; Lin, H. MSTRG.24008.1Long Non-coding RNA Regulates the Regeneration of the Sciatic Nerve via the miR-331-3p-NLRP3/MAL Axis. Front. Cell Dev. Biol. 2021, 9, 641603. [CrossRef] [PubMed]

61. Zhang, X.; Li, F.; Zhou, Y.; Mao, F.; Lin, Y.; Shen, S.; Li, Y.; Zhang, S.; Sun, Q. Long noncoding RNA AFAP1-AS1 promotes tumor progression and invasion by regulating the miR-2110/Sp1 axis in triple-negative breast cancer. Cell Death Dis. 2021, $12,627$. [CrossRef]

62. Yu, T.; Li, G.; Wang, C.; Gong, G.; Wang, L.; Li, C.; Chen, Y.; Wang, X. MIR210HG regulates glycolysis, cell proliferation, and metastasis of pancreatic cancer cells through miR-125b-5p/HK2/PKM2 axis. RNA Biol. 2021, 18, 1-18. [CrossRef] [PubMed]

63. Zhuang, M.; Deng, Y.; Zhang, W.; Zhu, B.; Yan, H.; Lou, J.; Zhang, P.; Cui, Q.; Tang, H.; Sun, H.; et al. LncRNA Bmp1 promotes the healing of intestinal mucosal lesions via the miR-128-3p/PHF6/PI3K/AKT pathway. Cell Death Dis. 2021, 12, 595. [CrossRef]

64. Da Rocha, S.; Boeva, V.; Escamilla-Del-Arenal, M.; Ancelin, K.; Granier, C.; Matias, N.; Sanulli, S.; Chow, J.; Schulz, E.; Picard, C.; et al. Jarid2 Is Implicated in the Initial Xist-Induced Targeting of PRC2 to the Inactive X Chromosome. Mol. Cell 2014, 53, 301-316. [CrossRef]

65. Marín-Béjar, O.; Marchese, F.; Athie, A.; Sánchez, Y.; González, J.; Segura, V.; Huang, L.; Moreno, I.; Navarro, A.; Monzó, M.; et al. Pint lincRNA connects the p53 pathway with epigenetic silencing by the Polycomb repressive complex 2. Genome Biol. 2013, 14, R104. [CrossRef]

66. Venkatraman, A.; He, X.; Thorvaldsen, J.; Sugimura, R.; Perry, J.; Tao, F.; Zhao, M.; Christenson, M.; Sanchez, R.; Yu, J.; et al. Maternal imprinting at the H19-Igf2 locus maintains adult haematopoietic stem cell quiescence. Nature 2013, 500, 345-349. [CrossRef]

67. Chen, D.; Zhang, Z.; Mao, C.; Zhou, Y.; Yu, L.; Yin, Y.; Wu, S.; Mou, X.; Zhu, Y. ANRIL inhibits p15(INK4b) through the TGFß1 signaling pathway in human esophageal squamous cell carcinoma. Cell. Immunol. 2014, 289, 91-96. [CrossRef] [PubMed]

68. Tang, Q.; Hann, S. HOTAIR: An Oncogenic Long Non-Coding RNA in Human Cancer. Cell. Physiol. Biochem. 2018, 47, 893-913. [CrossRef]

69. Faghihi, M.; Modarresi, F.; Khalil, A.; Wood, D.; Sahagan, B.; Morgan, T.; Finch, C.; St Laurent, G.; Kenny, P.; Wahlestedt, C. Expression of a noncoding RNA is elevated in Alzheimer's disease and drives rapid feed-forward regulation of beta-secretase. Nat. Med. 2008, 14, 723-730. [CrossRef] [PubMed]

70. Sun, J.; Wang, X.; Fu, C.; Wang, X.; Zou, J.; Hua, H.; Bi, Z. Long noncoding RNA FGFR3-AS1 promotes osteosarcoma growth through regulating its natural antisense transcript FGFR3. Mol. Biol. Rep. 2016, 43, 427-436. [CrossRef]

71. Zhu, Q.; Wang, S.; Shi, Y. LncRNA PCAT6 activated by SP1 facilitates the progression of breast cancer by the miR-326/LRRC8E axis. Anti-Cancer Drugs 2021. [CrossRef]

72. Wang, K.; Chang, H. Molecular mechanisms of long noncoding RNAs. Mol. Cell 2011, 43, 904-914. [CrossRef]

73. Ouyang, S.; Zhou, X.; Chen, Z.; Wang, M.; Zheng, X.; Xie, M. LncRNA BCAR4, targeting to miR-665/STAT3 signaling, maintains cancer stem cells stemness and promotes tumorigenicity in colorectal cancer. Cancer Cell Int. 2019, 19, 72. [CrossRef]

74. Wang, L.; Wang, X.; Yan, P.; Liu, Y.; Jiang, X. LINC00261 Suppresses Cisplatin Resistance of Esophageal Squamous Cell Carcinoma Through miR-545-3p/MT1M Axis. Front. Cell Dev. Biol. 2021, 9, 687788. [CrossRef]

75. Yang, X.; Wu, G.; Yang, F.; He, L.; Xie, X.; Li, L.; Yang, L.; Ma, Y.; Zhang, Q.; Chen, J.; et al. Elevated LINC00909 Promotes Tumor Progression of Ovarian Cancer via Regulating the miR-23b-3p/MRC2 Axis. Oxidative Med. Cell. Longev. 2021, $2021,5574130$. [CrossRef]

76. Sun, H.; Wang, T.; Zhang, W.; Dong, H.; Gu, W.; Huang, L.; Yan, Y.; Zhu, C.; Chen, Z. LncRNATUG1 Facilitates Th2 Cell Differentiation by Targeting the miR-29c/B7-H3 Axis on Macrophages. Front. Immunol. 2021, 12, 631450. [CrossRef] [PubMed]

77. Zhen, J.; Li, J.; Li, X.; Wang, X.; Xiao, Y.; Sun, Z.; Yu, Q. Downregulating lncRNA NEAT1 induces proliferation and represses apoptosis of ovarian granulosa cells in polycystic ovary syndrome via microRNA-381/IGF1 axis. J. Biomed. Sci. 2021, 28, 53. [CrossRef] [PubMed]

78. Wang, J.; Liu, X.; Wu, H.; Ni, P.; Gu, Z.; Qiao, Y.; Chen, N.; Sun, F.; Fan, Q. CREB up-regulates long non-coding RNA, HULC expression through interaction with microRNA-372 in liver cancer. Nucleic Acids Res. 2010, 38, 5366-5383. [CrossRef] [PubMed]

79. Salmena, L.; Poliseno, L.; Tay, Y.; Kats, L.; Pandolfi, P. A ceRNA hypothesis: The Rosetta Stone of a hidden RNA language? Cell 2011, 146, 353-358. [CrossRef]

80. Chan, J.; Tay, Y. Noncoding RNA: RNA regulatory networks in cancer. Int. J. Mol. Sci. 2018, 19, 1310. [CrossRef] [PubMed]

81. Lupinacci, S.; Perri, A.; Toteda, G.; Vizza, D.; Lofaro, D.; Pontrelli, P.; Stallone, G.; Divella, C.; Tessari, G.; La Russa, A.; et al. Rapamycin promotes autophagy cell death of Kaposi's sarcoma cells through P75NTR activation. Exp. Dermatol. 2021, 00, 1-11. [CrossRef]

82. Liang, W.; Shi, J.; Xia, H.; Wei, X. A Novel ruthenium-fluvastatin complex downregulates SNCG expression to modulate breast carcinoma cell proliferation and apoptosis via activating the PI3K/Akt/mTOR/VEGF/MMP9 pathway. Oxidative Med. Cell. Longev. 2021, 2021, 5537737. [CrossRef]

83. Shu, X.; Zhan, P.; Sun, L.; Yu, L.; Liu, J.; Sun, L.; Yang, Z.; Ran, Y.; Sun, Y. BCAT1 Activates PI3K/AKT/mTOR pathway and contributes to the angiogenesis and tumorigenicity of gastric cancer. Front. Cell Dev. Biol. 2021, 9, 659260. [CrossRef]

84. Zhao, Z.; Liu, H.; Hou, J.; Li, T.; Du, X.; Zhao, X.; Xu, W.; Xu, W.; Chang, J. Tumor protein D52 (TPD52) inhibits growth and metastasis in renal cell carcinoma cells through the PI3K/Akt signaling pathway. Oncol. Res. 2017, 25, 773-779. [CrossRef]

85. Wang, J.; Yang, W.; Chen, Z.; Chen, J.; Meng, Y.; Feng, B.; Sun, L.; Dou, L.; Li, J.; Cui, Q.; et al. Long noncoding RNA lncSHGL recruits hnRNPA1 to suppress hepatic gluconeogenesis and lipogenesis. Diabetes 2018, 67, 581-593. [CrossRef] 
86. Shi, X.; Ran, L.; Liu, Y.; Zhong, S.; Zhou, P.; Liao, M.; Fang, W. Knockdown of hnRNP A2/B1 inhibits cell proliferation, invasion and cell cycle triggering apoptosis in cervical cancer via PI3K/AKT signaling pathway. Oncol. Rep. 2018, 39, 939-950. [CrossRef] [PubMed]

87. Feng, J.; Liao, Y.; Xu, X.; Yi, Q.; He, L.; Tang, L. hnRNP A1 promotes keratinocyte cell survival post UVB radiation through PI3K/Akt/mTOR pathway. Exp. Cell Res. 2018, 362, 394-399. [CrossRef]

88. Choi, H.; Lee, H.; Jang, Y.; Kim, C.; Ryu, C. Heterogeneous nuclear ribonucleoprotein A2/B1 regulates the self-renewal and pluripotency of human embryonic stem cells via the control of the G1/S transition. Stem Cells 2013, 31, 2647-2658. [CrossRef]

89. Peng, Y.; Lin, H.; Liu, D.; Zhu, X.; Huang, N.; Wei, Y.; Li, L. Heat shock protein 90 inhibitor ameliorates pancreatic fibrosis by degradation of transforming growth factor- $\beta$ receptor. Cell. Signal. 2021, 84, 110001. [CrossRef] [PubMed]

90. Magaye, R.; Savira, F.; Hua, Y.; Xiong, X.; Huang, L.; Reid, C.; Flynn, B.; Kaye, D.; Liew, D.; Wang, B. Attenuating PI3K/AktmTOR pathway reduces dihydrosphingosine 1 phosphate mediated collagen synthesis and hypertrophy in primary cardiac cells. Int. J. Biochem. Cell Biol. 2021, 134, 105952. [CrossRef] [PubMed]

91. Song, Y.; Wang, Z.; Jiang, J.; Piao, Y.; Li, L.; Xu, C.; Piao, H.; Li, L.; Yan, G. DEK-targeting aptamer DTA-64 attenuates bronchial EMT-mediated airway remodelling by suppressing TGF- $\beta 1 /$ Smad, MAPK and PI3K signalling pathway in asthma. J. Cell. Mol. Med. 2020, 24, 13739-13750. [CrossRef]

92. Hong, X.; Wang, J.; Li, S.; Zhao, Z.; Feng, Z. MicroRNA-375-3p in endothelial progenitor cells-derived extracellular vesicles relieves myocardial injury in septic rats via BRD4-mediated PI3K/AKT signaling pathway. Int. Immunopharmacol. 2021, 96, 107740. [CrossRef] [PubMed]

93. Kang, X.; Kong, F.; Wu, S.; Liu, Q.; Yang, C.; Wu, X.; Zhang, W. microRNA-612 suppresses the malignant development of non-small-cell lung cancer by directly targeting bromodomain-containing protein 4 . OncoTargets Ther. 2019, 12, 4167-4179. [CrossRef]

94. Hao, J.; Yang, Z.; Wang, L.; Zhang, Y.; Shu, Y.; Jiang, L.; Hu, Y.; Lv, W.; Dong, P.; Liu, Y. Downregulation of BRD4 inhibits gallbladder cancer proliferation and metastasis and induces apoptosis via PI3K/AKT pathway. Int. J. Oncol. 2017, 51, 823-831. [CrossRef]

95. Wang, Y.; Lin, Q.; Song, C.; Ma, R.; Li, X. Circ_0007841 promotes the progression of multiple myeloma through targeting miR-338-3p/BRD4 signaling cascade. Cancer Cell Int. 2020, 20, 383. [CrossRef]

96. Zheng, S.; Lv, P.; Su, J.; Miao, K.; Xu, H.; Li, M. Overexpression of CBX2 in breast cancer promotes tumor progression through the PI3K/AKT signaling pathway. Am. J. Transl. Res. 2019, 11, 1668-1682. [PubMed]

97. Nusse, R.; Clevers, H. Wnt/ $\beta$-Catenin signaling, disease, and emerging therapeutic modalities. Cell 2017, 169, 985-999. [CrossRef] [PubMed]

98. Kaplan, Z.; Zielske, S.; Ibrahim, K.; Cackowski, F. WNT and $\beta$-catenin signaling in the bone metastasis of prostate cancer. Life 2021, 11, 1099. [CrossRef]

99. Martin-Orozco, E.; Sanchez-Fernandez, A.; Ortiz-Parra, I.; Ayala-San Nicolas, M. WNT signaling in tumors: The way to evade drugs and immunity. Front. Immunol. 2019, 10, 2854. [CrossRef]

100. Farahmand, L.; Darvishi, B.; Majidzadeh-A, A.; Madjid Ansari, A. Naturally occurring compounds acting as potent antimetastatic agents and their suppressing effects on Hedgehog and WNT/ $\beta$-catenin signalling pathways. Cell Prolif. 2017, 50, e12299. [CrossRef]

101. Wang, G.; Ma, C.; Shi, X.; Guo, W.; Niu, J. miR-107 enhances the sensitivity of breast cancer cells to paclitaxel. Open Med. 2019, 14, 456-466. [CrossRef]

102. Fu, Y.; Katsaros, D.; Biglia, N.; Wang, Z.; Pagano, I.; Tius, M.; Tiirikainen, M.; Rosser, C.; Yang, H.; Yu, H. Vitamin D receptor upregulates lncRNA TOPORS-AS1 which inhibits the Wnt/ $\beta$-catenin pathway and associates with favorable prognosis of ovarian cancer. Sci. Rep. 2021, 11, 7484. [CrossRef]

103. Liu, Y.; Li, H.; Liu, F.; Gao, L.; Han, R.; Chen, C.; Ding, X.; Li, S.; Lu, K.; Yang, L.; et al. Heterogeneous nuclear ribonucleoprotein $\mathrm{A} 2 / \mathrm{B} 1$ is a negative regulator of human breast cancer metastasis by maintaining the balance of multiple genes and pathways. EBioMedicine 2020, 51, 102583. [CrossRef] [PubMed]

104. Wang, J.; Quan, Y.; Lv, J.; Gong, S.; Dong, D. BRD4 promotes glioma cell stemness via enhancing miR-142-5p-mediated activation of Wnt/ $\beta$-catenin signaling. Environ. Toxicol. 2020, 35, 368-376. [CrossRef] [PubMed]

105. Song, H.; Shi, L.; Xu, Y.; Xu, T.; Fan, R.; Cao, M.; Xu, W.; Song, J. BRD4 promotes the stemness of gastric cancer cells via attenuating miR-216a-3p-mediated inhibition of Wnt/ $\beta$-catenin signaling. Eur. J. Pharmacol. 2019, 852, 189-197. [CrossRef]

106. Wang, K.; Zhao, Z.; Wang, X.; Zhang, Y. BRD4 induces osteogenic differentiation of BMSCs via the Wnt/ $\beta$-catenin signaling pathway. Tissue Cell 2021, 72, 101555. [CrossRef]

107. Dou, Y.; Chen, F.; Lu, Y.; Qiu, H.; Zhang, H. Effects of Wnt/ $\beta$-catenin signal pathway regulated by miR-342-5p targeting CBX2 on proliferation, metastasis and invasion of ovarian cancer cells. Cancer Manag. Res. 2020, 12, 3783-3794. [CrossRef]

108. Garcia-Moreno, S.; Lin, Y.; Futtner, C.; Salamone, I.; Capel, B.; Maatouk, D. CBX2 is required to stabilize the testis pathway by repressing Wnt signaling. PLoS Genet. 2019, 15, e1007895. [CrossRef]

109. Ma, Y.; Li, R.; Zhang, Y.; Zhou, L.; Dai, Y. Knockdown of peroxiredoxin 5 inhibits the growth of osteoarthritic chondrocytes via upregulating Wnt/ $\beta$-catenin signaling. Free Radic. Biol. Med. 2014, 76, 251-260. [CrossRef]

110. Lamouille, S.; Xu, J.; Derynck, R. Molecular mechanisms of epithelial-mesenchymal transition. Nat. Rev. Mol. Cell Biol. 2014, 15, 178-196. [CrossRef] 
111. Kalluri, R.; Weinberg, R. The basics of epithelial-mesenchymal transition. J. Clin. Investig. 2009, 119, 1420-1428. [CrossRef] [PubMed]

112. Chaffer, C.; San Juan, B.; Lim, E.; Weinberg, R. EMT, cell plasticity and metastasis. Cancer Metastasis Rev. 2016, 35, 645-654. [CrossRef]

113. Lambert, A.; Pattabiraman, D.; Weinberg, R. Emerging biological principles of metastasis. Cell 2017, 168, 670-691. [CrossRef]

114. Wang, H.; Xiao, Z.; Zheng, J.; Wu, J.; Hu, X.; Yang, X.; Shen, Q. ZEB1 Represses neural differentiation and cooperates with CTBP2 to dynamically regulate cell migration during neocortex development. Cell Rep. 2019, 27, 2335-2353.e6. [CrossRef] [PubMed]

115. Liang, H.; Yu, T.; Han, Y.; Jiang, H.; Wang, C.; You, T.; Zhao, X.; Shan, H.; Yang, R.; Yang, L.; et al. LncRNA PTAR promotes EMT and invasion-metastasis in serous ovarian cancer by competitively binding miR-101-3p to regulate ZEB1 expression. Mol. Cancer 2018, 17, 119. [CrossRef] [PubMed]

116. Luo, F.; Wei, H.; Guo, H.; Li, Y.; Feng, Y.; Bian, Q.; Wang, Y. LncRNA MALAT1, an IncRNA acting via the miR-204/ZEB1 pathway, mediates the EMT induced by organic extract of PM in lung bronchial epithelial cells. Am. J. Physiol. Lung Cell. Mol. Physiol. 2019, 317, L87-L98. [CrossRef]

117. Dong, N.; Tang, X.; Yuan, X.; Song, H.; Li, J. [TAK1 promotes epithelial-mesenchymal transition of lens epithelial cells]. Chin. J. Ophthalmol. 2016, 52, 278-284. [CrossRef]

118. Gardner, A.; Fisher, A.; Richter, C.; Johnson, G.; Moisey, E.; Brodlie, M.; Ward, C.; Krippner-Heidenreich, A.; Mann, D.; Borthwick, L. The critical role of TAK1 in accentuated epithelial to mesenchymal transition in obliterative bronchiolitis after lung transplantation. Am. J. Pathol. 2012, 180, 2293-2308. [CrossRef]

119. Li, J.; Li, Y.; Jin, W.; Yang, Q.; Shao, Z.; Tian, X. ABT-737 reverses the acquired radioresistance of breast cancer cells by targeting Bcl-2 and Bcl-xL. J. Exp. Clin. Cancer Res. 2012, 31, 102. [CrossRef]

120. Zhu, J.; Chen, S.; Yang, B.; Mao, W.; Yang, X.; Cai, J. Molecular mechanisms of lncRNAs in regulating cancer cell radiosensitivity. Biosci. Rep. 2019, 39, BSR20190590. [CrossRef]

121. Zhu, C.; Li, K.; Jiang, M.; Chen, S. RBM5-AS1 promotes radioresistance in medulloblastoma through stabilization of SIRT6 protein. Acta Neuropathol. Commun. 2021, 9, 123. [CrossRef] [PubMed]

122. Liu, Y.; Chen, X.; Chen, X.; Liu, J.; Gu, H.; Fan, R.; Ge, H. Long non-coding RNA HOTAIR knockdown enhances radiosensitivity through regulating microRNA-93/ATG12 axis in colorectal cancer. Cell Death Dis. 2020, 11, 175. [CrossRef] [PubMed]

123. He, Y.; Jing, Y.; Wei, F.; Tang, Y.; Yang, L.; Luo, J.; Yang, P.; Ni, Q.; Pang, J.; Liao, Q.; et al. Long non-coding RNA PVT1 predicts poor prognosis and induces radioresistance by regulating DNA repair and cell apoptosis in nasopharyngeal carcinoma. Cell Death Dis. 2018, 9, 235. [CrossRef]

124. Assaraf, Y.; Brozovic, A.; Gonçalves, A.; Jurkovicova, D.; Linē, A.; Machuqueiro, M.; Saponara, S.; Sarmento-Ribeiro, A.; Xavier, C.; Vasconcelos, M. The multi-factorial nature of clinical multidrug resistance in cancer. Drug Resist. Updates 2019, $46,100645$. [CrossRef]

125. Levin, M.; Stark, M.; Berman, B.; Assaraf, Y. Surmounting Cytarabine-resistance in acute myeloblastic leukemia cells and specimens with a synergistic combination of hydroxyurea and azidothymidine. Cell Death Dis. 2019, 10, 390. [CrossRef]

126. Yeldag, G.; Rice, A.; Del Río Hernández, A. Chemoresistance and the self-maintaining tumor microenvironment. Cancers 2018, 10, 471. [CrossRef]

127. Wambecke, A.; Ahmad, M.; Morice, P.; Lambert, B.; Weiswald, L.; Vernon, M.; Vigneron, N.; Abeilard, E.; Brotin, E.; Figeac, M.; et al. The lncRNA 'UCA1' modulates the response to chemotherapy of ovarian cancer through direct binding to miR-27a-5p and control of UBE2N levels. Mol. Oncol. 2021. [CrossRef]

128. Chen, S.; Yang, M.; Wang, C.; Ouyang, Y.; Chen, X.; Bai, J.; Hu, Y.; Song, M.; Zhang, S.; Zhang, Q. Forkhead box D1 promotes EMT and chemoresistance by upregulating lncRNA CYTOR in oral squamous cell carcinoma. Cancer Lett. 2021, 503, 43-53. [CrossRef]

129. Zheng, Z.; Li, Z.; Guan, J.; Liu, X.; Li, J.; Chen, Y.; Lin, L.; Kou, J.; Lv, J.; Zhang, L.; et al. Long Noncoding RNA TINCR-Mediated Regulation of Acetyl-CoA Metabolism Promotes Nasopharyngeal Carcinoma Progression and Chemoresistance. Cancer Res. 2020, 80, 5174-5188. [CrossRef]

130. Sun, Y.; Xu, J. TCF-4 Regulated lncRNA-XIST Promotes M2 polarization of macrophages and is associated with lung cancer. OncoTargets Ther. 2019, 12, 8055-8062. [CrossRef] [PubMed]

131. Yin, Z.; Zhou, Y.; Ma, T.; Chen, S.; Shi, N.; Zou, Y.; Hou, B.; Zhang, C. Down-regulated lncRNA SBF2-AS1 in M2 macrophagederived exosomes elevates miR-122-5p to restrict XIAP, thereby limiting pancreatic cancer development. J. Cell. Mol. Med. 2020, 24, 5028-5038. [CrossRef]

132. Jiang, H.; Shi, X.; Ye, G.; Xu, Y.; Xu, J.; Lu, J.; Lu, W. Up-regulated long non-coding RNA DUXAP8 promotes cell growth through repressing Krüppel-like factor 2 expression in human hepatocellular carcinoma. OncoTargets Ther. 2019, 12, 7429-7436. [CrossRef] [PubMed]

133. Yu, L.; Wei, J.; Liu, P. Attacking the PI3K/Akt/mTOR signaling pathway for targeted therapeutic treatment in human cancer. Semin. Cancer Biol. 2021, 25, S1044-579X(21)00188-7. [CrossRef]

134. Tewari, D.; Bawari, S.; Sharma, S.; DeLiberto, L.; Bishayee, A. Targeting the crosstalk between canonical Wnt/ $\beta$-catenin and inflammatory signaling cascades: A novel strategy for cancer prevention and therapy. Pharmacol. Ther. 2021, $227,107876$. [CrossRef] [PubMed] 
135. Sharma, A.; Yeow, W.; Ertel, A.; Coleman, I.; Clegg, N.; Thangavel, C.; Morrissey, C.; Zhang, X.; Comstock, C.; Witkiewicz, A.; et al. The retinoblastoma tumor suppressor controls androgen signaling and human prostate cancer progression. J. Clin. Investig. 2010, 120, 4478-4492. [CrossRef] [PubMed]

136. Campbell, H.; Fleming, N.; Roth, I.; Mehta, S.; Wiles, A.; Williams, G.; Vennin, C.; Arsic, N.; Parkin, A.; Pajic, M.; et al. $\Delta 133$ p53 isoform promotes tumour invasion and metastasis via interleukin-6 activation of JAK-STAT and RhoA-ROCK signalling. Nat. Commun. 2018, 9, 254. [CrossRef] [PubMed] 